UNIVERSIDADE DE BRASÍLIA

INSTITUTO DE CIÊNCIAS BIOLÓGICAS

DEPARTAMETO DE FITOPATOLOGIA

PROGRAMA DE PÓS-GRADUAÇÃO EM FITOPATOLOGIA

\title{
POPULAÇÕES DE NEMATOIDES FITOPARASITAS EM ÁREAS DE CULTIVO DE SOJA, ALGODÃO, CAFÉ E DE VEGETAÇÃO NATIVA DO CERRADO NA REGIÃO OESTE DA BAHIA.
}

CARINA MARIANI LEITE LOPES

BRASÍLIA - DF 


\title{
CARINA MARIANI LEITE LOPES
}

\section{POPULAÇÕES DE NEMATOIDES FITOPARASITAS EM ÁREAS DE CULTIVO DE SOJA, ALGODÃO, CAFÉ E DE VEGETAÇÃO NATIVA DO CERRADO NA REGIÃO OESTE DA BAHIA.}

\author{
Dissertação apresentada à Universidade \\ de Brasília como requisito parcial para \\ obtenção de título de Mestre em \\ Fitopatologia pelo Programa de Pós- \\ graduação em Fitopatologia.
}

\section{Orientador}

Prof. Juvenil Enrique Cares, Doutor.

BRASÍLIA - DF

DISTRITO FEDERAL - BRASIL 


\section{FICHA CATALOGRÁFICA}

Lopes, Carina Mariani Leite.

Populações de nematoides fitoparasitas em áreas de cultivo de soja, algodão, café e de vegetação nativa do Cerrado na região Oeste da Bahia. / Carina Mariani Leite Lopes.

Brasília, 2015.

70p. : il.

Dissertação de mestrado. Programa de Pós-graduação em Fitopatologia, Universidade de Brasília, Brasília.

1. Levantamento - Fitonematoides.

I. Universidade de Brasília. PPG/FIT.

II. Populações de nematoides fitoparasitas em áreas de cultivo de soja, algodão, café e de vegetação nativa do Cerrado na região Oeste da Bahia. 


\section{AGRADECIMENTOS}

À Deus, por ser minha fonte inesgotável de fé, força e confiança,

Aos meus amados pais Sérgia Maria e José Cisino, meus irmãos Maurício, Rafael, Tiago e Samuel, Tia Stela e demais familiares por terem acreditado em mim em todos os momentos da minha vida me oferecendo seu apoio e amor incondicionais.

Ao meu querido orientador Professor Juvenil Enrique Cares por ter confiado em mim e no meu trabalho, pela paciência e por toda ajuda durante a realização deste projeto.

Ao Professor Cleber Furlanetto, pelos conselhos concedidos e por aceitar participar da banca examinadora.

Ao Professor João Luiz Coimbra por ter acompanhado toda a minha vida acadêmica desde a graduação até a defesa do mestrado com disposição e amizade, e por ter aberto as portas do Laboratório de Nematologia da Universidade do Estado da Bahia - UNEB para o processamento das amostras.

À Universidade de Brasília - UnB/ Departamento de Fitopatologia pela oportunidade de realizar o mestrado.

Aos meus professores durante o período do mestrado: Juvenil Cares, Cleber Furlanetto, Adalberto Café Filho, Marisa Sanches, Carlos Uesugui, Helson do Vale, Rita Carvalho, Renato Resende, Carlos Lopes, Robert Miller, José Carmine Dianese, e especialmente ao querido amigo professor Claudio Lucio, por terem dividido seus conhecimentos comigo e com meus colegas sempre com muita dedicação e paciência.

À CAPES - Coordenação de Aperfeiçoamento de Pessoal de Nível Superior pela concessão de bolsa. 
À Associação de Agricultores e Irrigantes da Bahia por ter concedido todo o suporte logístico para a coleta das amostras e para o transporte de material de Barreiras para Brasília.

Ao senhor José Cisino, Diretor da Associação de Agricultores e Irrigantes da Bahia, por ter me acompanhado e ajudado em todas as coletas de solo, sem você esse trabalho não teria sido realizado.

Aos proprietários das fazendas que permitiram nosso acesso irrestrito às áreas de plantio e que em diversas ocasiões disponibilizaram os técnicos de campo para ajudar nas coletas.

Aos amigos Cristiano Rodrigues, Magno Alves, Uender Antunes, Gildasio Rego e Marta Cambuí pela ajuda nas coletas de solo.

Aos colegas do Laboratório de Nematologia do Departamento de Fitopatologia da UnB pela paciência nos meus momentos de estresse, e especialmente a minha amiga Nancy Ninõ pela ajuda na identificação dos nematoides e auxílio na realização das reações de eletroforese.

Aos grandes amigos que conheci durante esses quase dois anos de mestrado e que estiveram sempre do meu lado torcendo por mim e fazendo com que esse momento fosse um dos mais felizes da mina vida.

Meus sinceros agradecimentos! 
Trabalho realizado junto ao Departamento de Fitopatologia do Instituto de Ciências Biológicas da Universidade de Brasília, sob orientação do Professor Juvenil Enrique Cares, com apoio da Coordenação de Aperfeiçoamento de Pessoal de Nível Superior - CAPES.

POPULAÇÕES DE NEMATOIDES FITOPARASITAS EM ÁREAS DE CULTIVO DE SOJA, ALGODÃO, CAFÉ E DE VEGETAÇÃO NATIVA DO CERRADO NA REGIÃO OESTE DA BAHIA.

\section{CARINA MARIANI LEITE LOPES}

Dissertação Aprovada em 25 de fevereiro de 2015 por:

Prof. Cleber Furlanetto

Examinador Interno

Prof. João Luiz Coimbra

Examinador Externo

Prof. Juvenil Enrique Cares

Orientador (Presidente)

BRASÍLIA - DISTRITO FEDERAL

BRASIL 


\section{SUMÁRIO}

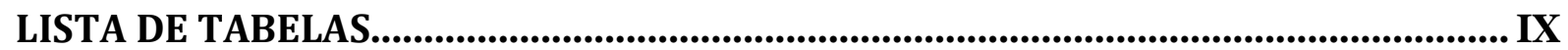

LISTA DE FIGURAS ...................................................................................................................X

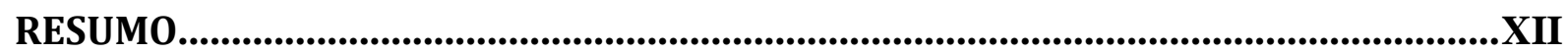

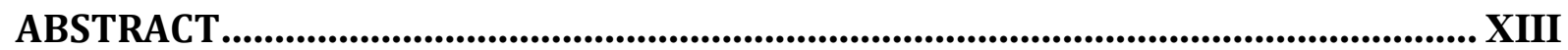

1. INTRODUÇÃO.....................................................................................................................1

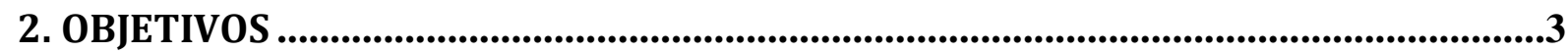

3. REFERENCIAL TEÓRICO ............................................................................................4

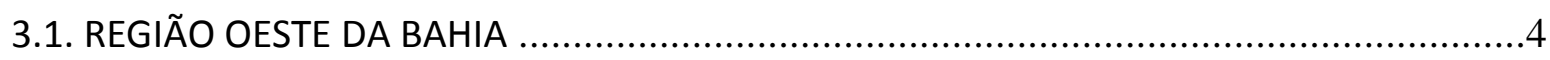

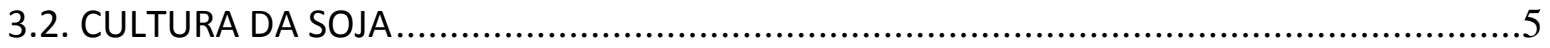

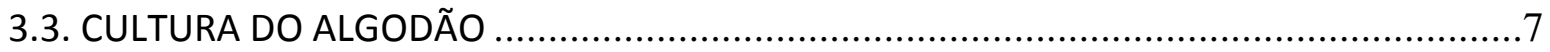

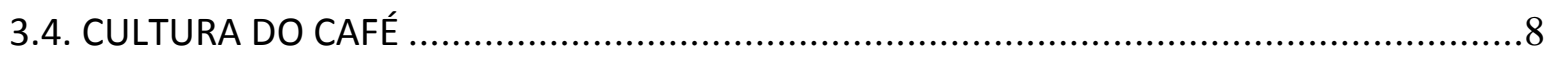

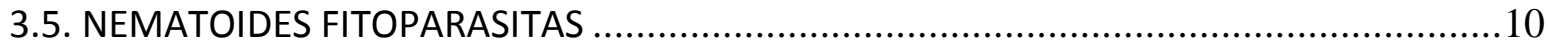

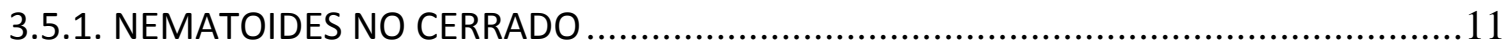

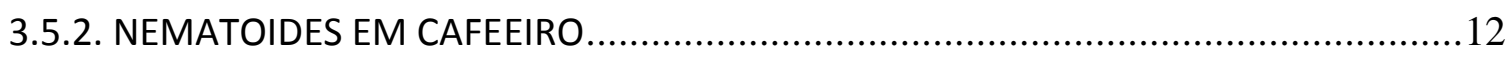

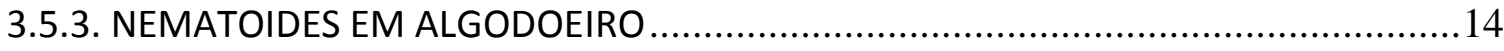

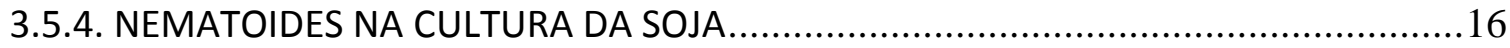

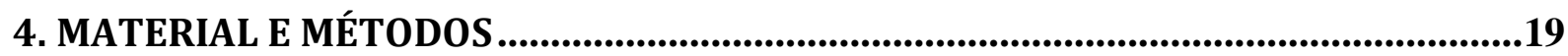

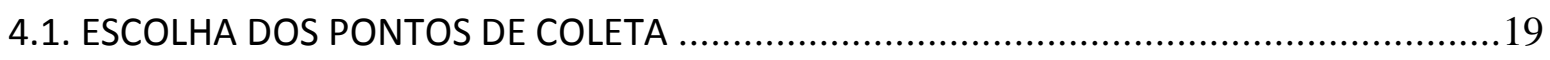

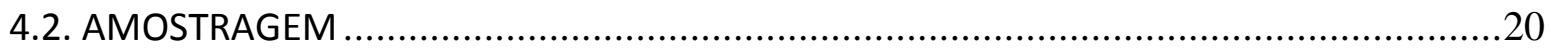

4.3. MULTIPLICAÇÃO DAS POPULAÇÕES DE Meloidogyne spp.......................................22

4.4. PROCESSAMENTO DAS AMOSTRAS DE SOLO PARA QUANTIFICAÇÃO DOS

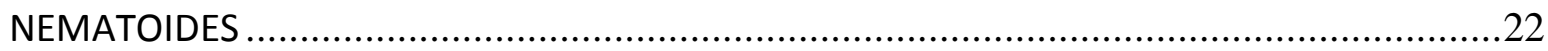

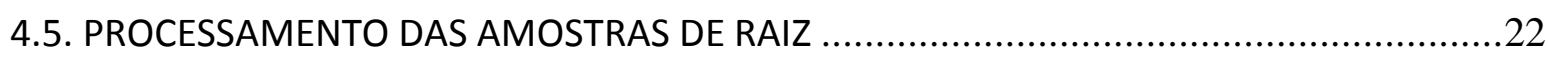




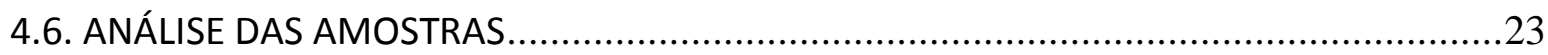

4.7. IDENTIFICAÇÃO DE ESPÉCIES DE Meloidogyne .........................................................23

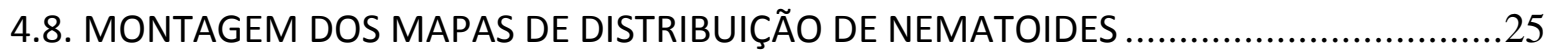

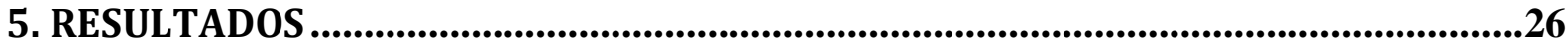

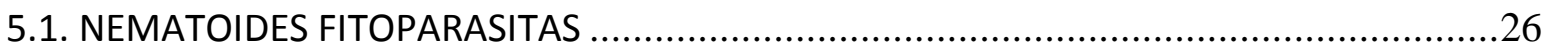

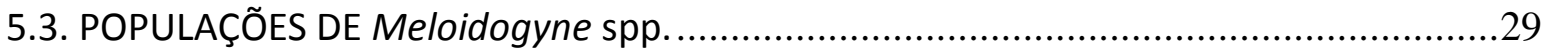

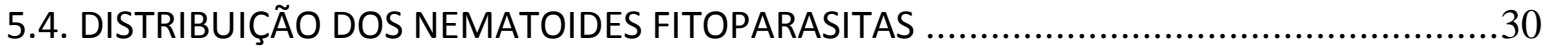

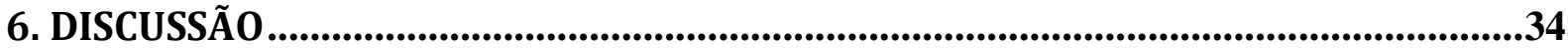

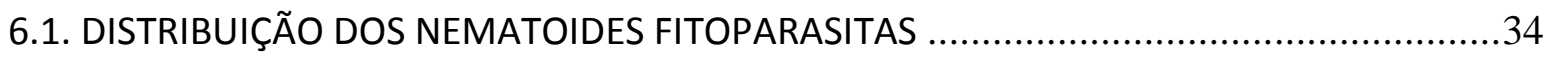

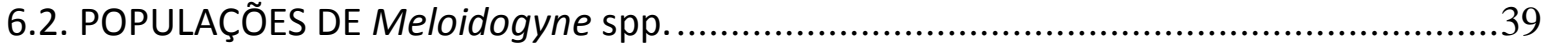

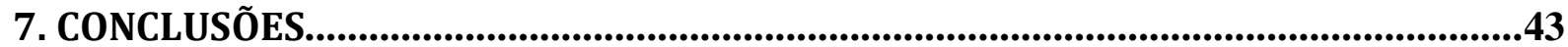

REFERÊNCIAS BIBLIOGRÁFICAS ............................................................................44 


\section{LISTA DE TABELAS}

Tabela 1. Frequência (\%) das populações de nematoides fitoparasitas encontrados em 75 amostras de solo e raízes para cada cultura e vegetação nativa de cerrado do oeste da Bahia.

Tabela 2. Valores mínimos e máximos das populações de nematoides fitoparasitas encontrados em amostras de $300 \mathrm{~cm}^{3}$ de solo e $10 \mathrm{~g}$ de raízes, coletadas em plantios de soja no Oeste da Bahia

Tabela 3. Valores mínimos e máximos das populações de nematoides fitoparasitas encontrados em amostras de $300 \mathrm{~cm}^{3}$ de solo e $10 \mathrm{~g}$ de raízes, coletadas em plantios de algodão no Oeste da Bahia.

Tabela 4. Valores mínimos e máximos das populações de nematoides fitoparasitas encontrados em amostras de $300 \mathrm{~cm}^{3}$ de solo e $10 \mathrm{~g}$ de raízes, coletadas em plantios de café no Oeste da Bahia. .39

Tabela 5. Valores mínimos e máximos das populações de nematoides fitoparasitas encontrados em amostras de $300 \mathrm{~cm}^{3}$ de solo e $10 \mathrm{~g}$ de raízes, coletadas em áreas de cerrado no Oeste da Bahia. 


\section{LISTA DE FIGURAS}

Figura 1. Pontos de coleta das amostras em áreas de soja, algodão, café e cerrado na região oeste da Bahia. .20

Figura 2. Esquema de amostragem aleatória de pontos de coleta em uma fazenda (áreas de soja, algodão e cerrado preservado. .21

Figura 3. 3A: Esquema de amostragem em circulo em áreas de plantio de soja, algodão ou cerrado. 3B: Esquema de amostragem em áreas de plantio de café com sistema de pivô central. .21

Figura 4. Padrões de bandas da isoenzima esterase para espécies de Meloidogyne (CARNEIRO E COFCEWICZ, 2008). .25

Figura 5. Padrões da isoenzima esterase encontrados nos géis de poliacrilamida para as espécies Meloidogyne incognita e M. javanica encontradas em amostras de solo coletadas no Oeste da Bahia 30

Figura 6. Mapa da distribuição de Pratylenchus spp. na região oeste da Bahia e o tamanho das populações encontradas em cada local de amostragem em $10 \mathrm{~g}$ de raízes. .31

Figura 7. Mapa da distribuição de Meloidogyne spp. na região oeste da Bahia e o tamanho das populações encontradas em cada local de amostragem em $300 \mathrm{~cm}^{3}$ de solo

Figura 8. Mapa da distribuição de Rotylenchulus reniformis na região oeste da Bahia e o tamanho das populações encontradas em cada local de amostragem em $300 \mathrm{~cm}^{3}$ de solo 32

Figura 9. Mapa da distribuição de Helicotylenchus spp. na região oeste da Bahia e o tamanho das populações encontradas em cada local de amostragem em $300 \mathrm{~cm}^{3}$ de solo 
Figura 10. Mapa da distribuição de Hemicycliophora spp. na região oeste da Bahia e os intervalos das populações encontradas em $300 \mathrm{~cm}^{3}$ de solo........................................................33

Figura 11. Mapa da distribuição de Heterodera glycines (J2) na região oeste da Bahia e os intervalos das populações encontradas em $300 \mathrm{~cm}^{3}$ de solo.............................................................33 


\section{RESUMO}

LOPES, Carina Mariani Leite. Populações de nematoides fitoparasitas em áreas de cultivo de soja, algodão, café e de vegetação nativa do Cerrado na região Oeste da Bahia. 2015. (70p). Dissertação (Mestrado em Fitopatologia) - Universidade de Brasília, Brasília - DF.

A região oeste da Bahia, um importante polo de produção agrícola do país, tem sofrido perdas de produção nas culturas devido à ação de organismos fitopatogênicos, em especial nematoides fitoparasitas. A adoção de estratégias adequadas de controle de fitonematoides envolve o conhecimento prévio das espécies e suas populações existentes no solo. Com o objetivo de estudar as populações de fitonematoides presentes na região oeste da Bahia, foram coletadas 300 amostras de solo e raízes em cultivos de café, soja, algodão e áreas de reserva legal de cerrado, no período de janeiro a abril de 2014, em fazendas localizadas nos municípios de Barreiras, Luis Eduardo Magalhães, Formosa do Rio Preto, São Desidério, Riachão das Neves e Baianópolis. Nematoides fitoparasitas foram extraídos de amostras de solo e raízes e identificados com auxílio de microscópio óptico. Espécies de Meloidogyne foram identificadas pelo fenótipo da isoenzima esterase. Foram encontrados espécimes de 14 gêneros fitoparasitas, a saber: Pratylenchus, Helicotylenchus, Meloidogyne, Rotylenchulus, Heterodera, Hemicycliophora, Scutellonema, Hoplolaimus, Gracilacus, Criconemoides, Discocriconemella, Nothocriconemoides, Trichodorus e Paratrichodorus. Espécimes do gênero Helicotylenchus foram os mais frequentes nas amostras de solo $(58,3 \%)$ seguido por Pratylenchus (52,3\%). Das espécies de Meloidogyne, M. javanica prevaleceu em relação as demais. Juvenis de Heterodera somente foram identificados em seis fazendas nos municípios de Formosa do Rio Preto, São Desidério e Barreiras. Hemicycliophora spp. estiveram presentes em $69,3 \%$ das amostras coletadas em cultivos de café.

Palavras-chave: Fitonematoides, Levantamento, Oeste da Bahia

Orientador - Juvenil Enrique Cares - Universidade de Brasília. 


\section{ABSTRACT}

LOPES, Carina Mariani Leite. Populations of plant-parasitic nematode in growing areas of soybean, cotton, coffee and native vegetation of Cerrado in Western Bahia. 2015. (70p). Dissertation (Master in Plant Pathology) - Universidade de Brasília, Brasília - DF, Brazil.

The region western of Bahia, an a important agricultural center of Brazil, has suffered crop losses due to the action of pathogenic organisms in the plantations, mainly plant-parasitic nematodes. The adoption of appropriate strategies to control plant-parasitic nematodes, envolves prior knowledge on the species and its populations in the soil. In order to assess the populations of plant parasitic nematodes in western Bahia, 300 soil and roots samples were collected in coffee, soybean and cotton plantations as well as in surrounding native vegetation of cerrado, from January to April 2014, in farms located in the municipalities of Barreiras, Luis Eduardo Magalhães, Formosa do Rio Preto, São Desidério, Riachão das Neves and Baianópolis. Nematodes were extracted from the soil and root samples and identified under light microscope. Species of Meloidogyne were identified by esterase phenotypes. Specimens of genera of plant-parasitic nematodes were found, namely: Pratylenchus Helicotylenchus, Meloidogyne, Rotylenchulus, Heterodera, Hemicycliophora, Scutellonema, Hoplolaimus, Gracilacus, Criconemoides, Discocriconemella, Nothocriconemoides, Trichodorus and Paratrichodorus. Specimens of Helicotylenchus were the most frequent in the samples (58,3\%) followed by Pratylenchus (52,3\%). The species of Meloidogyne most commonly found was M. javanica. Juveniles of Heterodera were identified in only six farms in the municipalities of Formosa do Rio Preto, São Desidério and Barreiras. Hemicycliophora spp. was present in $69,3 \%$ of the samples collected in coffee plantations.

Keywords: Plant-parasitic nematodes, Survey, Western Bahia.

Advisor - Juvenil Enrique Cares - Universidade de Brasília. 


\section{INTRODUÇÃO}

A região oeste do Estado da Bahia abriga uma vasta área do bioma Cerrado, devido a incentivos como financiamentos, baixos custos da terra, estações chuvosas definidas e amplas áreas de terras planas que permitem a mecanização, essa região despontou como uma fronteira agrícola nos anos 1980 e hoje já está consolidada como um importante polo produtivo do Brasil. Apesar de seu solo predominantemente latossolo amarelo álico de baixa fertilidade natural, alta acidez e alta saturação de alumínio, a agricultura alcançou grande sucesso nessa região devido aos elevados investimentos em tecnologias, adubação, correção do solo e irrigação. Atualmente a Região Oeste da Bahia é responsável por 27,4\% da produção de algodão, 4,5\% da produção de soja e 4,9\% da produção de milho do Brasil, além de $20 \%$ da produção de café da Bahia, alcançando recordes de produtividade nessas culturas a cada ano (CONAB, 2014; IBGE, 2014).

Em contra ponto, a vegetação nativa de Cerrado vem sendo aos poucos substituída por monoculturas, principalmente das commodities soja, algodão, milho e café. A exploração dessa região com a agricultura tem uma história recente e até então tem sido bastante promissora. No entanto, nos últimos anos surgiram problemas fitossanitários como a disseminação de doenças e o ataque de pragas que até então não preocupavam os produtores da região. Perdas causadas pela presença de fitonematoides se inserem nesse contexto. Os nematoides estão naturalmente presentes no solo em relativo equilíbrio, no entanto, áreas extensas sendo cultivadas com poucas espécies de plantas por períodos de tempo prolongados, favorecem a multiplicação de nematoides que parasitam tais plantas e, com o passar dos anos, perdas causadas por esses organismos começam a ser percebidas. Os danos causados pelos nematoides variam de acordo com a cultura, com as espécies de nematoides presentes e com as interações dos nematoides com outros fitopatógenos. Alguns estudos demonstraram a ocorrência de espécies de nematoides com potencial de causar prejuízos para 
agricultura da região oeste da Bahia como o Heterodera glycines Ichinohe, 1952 na soja (DIAS et al., 2006), Meloidogyne incognita (Kofoid e White, 1919) Chitwood, 1949, Pratylenchus brachyurus (Godfrey, 1929) Filipjev e Sch. Sttekhoven, 1941 e Rotylenchulus reniformis Linford e Oliveira, 1940 em algodão (MATOS et al., 2010; SANTOS, 2005).

Levando-se em consideração o progresso das populações de fitonematoides em ambientes agrícolas e a dificuldade de atuação direta contra tais patógenos, devido sua capacidade de sobrevivência no solo e em diversas plantas, justifica-se investigar qual o real panorama da presença dos nematoides e do potencial desses organismos em causar perdas à agricultura da região oeste da Bahia, para que se possam tomar medidas de controle adequadas ao real nível de risco representado por estes organismos. 


\section{OBJETIVOS}

Geral:

Conhecer o panorama atual das populações de fitonematoides que ocorrem no cerrado do Oeste Baiano, nos cultivos de soja, algodão e café bem como os níveis populacionais dos fitonematoides que habitam solos de vegetação nativa vizinhas às áreas cultivadas.

Específicos:

Identificar os fitonematoides e os respectivos níveis populacionais contidos nas amostras de solo e raízes.

Identificar as espécies de nematoides do gênero Meloidogyne através de perfis da enzima esterase.

Montar mapas da distribuição das populações dos fitonematoides na região Oeste da Bahia. 


\section{REFERENCIAL TEÓRICO}

\subsection{REGIÃO OESTE DA BAHIA}

A região Oeste da Bahia, atualmente a principal fronteira agrícola do Estado, recebeu no fim da década de 1970 muitos emigrantes do sul do país, que saíram em busca de maiores áreas para cultivo nas novas fronteiras agrícolas que estavam sendo abertas no Cerrado. As primeiras cidades no oeste baiano que receberam esse fluxo migratório de agricultores do sul do Brasil foram Barreiras, São Desidério e Luís Eduardo Magalhães (COSTA \& MONARDO, 2013).

Nas décadas de 1980 e 1990, a região conheceu uma expansão agropecuária sem precedentes, e devido ao acréscimo significativo em áreas de cultivo de grãos, cultivos perenes e na agricultura irrigada, o desenvolvimento dessa região fez da Bahia um importante polo produtor nacional de grãos, café, carnes, frutas e fibras (MENDONÇA, 2006).

A região oeste da Bahia é caracterizada pela variação de clima úmido, úmido a subúmido e seco a subúmido, com duas estações bem definidas no decorrer do ano, uma úmida e quente, de novembro a abril, e outra seca e fria, de julho a outubro. A vegetação é predominantemente de cerrado arbóreo aberto sem florestas de galeria e os solos são classificados como latossolo vermelho-amarelo-álico e areia quartzosa álica, com topografia plana e presença de uma bacia hidrográfica capaz de oferecer suporte para projetos de irrigação, composta por rios perenes e de grande volume d'água (MENDONÇA, 2006; SOUZA et al., 2010).

Na região oeste da Bahia a área de solo sob vegetação de cerrados abrange oito milhões de hectares aproximadamente, dos quais 2,25 milhões de hectares estão sendo efetivamente utilizados para agricultura (AIBA, 2014). 
Atualmente, o oeste baiano ocupa uma posição de destaque no cenário nacional como um dos principais expoentes do agronegócio globalizado, além de apresentar um elevado crescimento demográfico e econômico (ILARIO, 2013). O sucesso da agricultura no oeste da Bahia pode ser comprovado pelos dados da produção de commodities agrícolas, destacandose a produção de algodão que na safra 2013/14 chegou a 1,25 milhão de toneladas, representando $27,4 \%$ da produção nacional; a produção de soja que foi de 3,3 milhões de toneladas, atingindo uma das maiores produtividades nacionais do grão, de 42 sacas/ha; a produção de milho com um total de 2,34 milhões de toneladas colocando a região como a maior produtora do grão do norte e nordeste do país; e a produção de café irrigado que embora ocupe uma área 14.704 ha, pequena em comparação com as demais culturas, alcança produtividade de 39,28 sacas/ha, a maior dentre as regiões produtoras do Brasil (AIBA, 2014; CONAB, 2014; IBGE 2014).

\subsection{CULTURA DA SOJA}

De acordo com os primeiros relatos, a produção de soja, Glycine max (L.) Merrill foi exclusiva da China até a guerra China-Japão, de 1894 a 1895, quando os japoneses começaram a importar a soja como fertilizante (EMBRAPA, 2000). A soja chegou ao Brasil via Estados Unidos, em 1882. Gustavo Dutra, então professor da Escola de Agronomia da Bahia, realizou os primeiros estudos de avaliação de cultivares daquele país. Em 1891, testes de adaptação de cultivares, semelhantes aos conduzidos por Dutra na Bahia, foram realizados no Instituto Agronômico de Campinas, Estado de São Paulo. Entre 1900 e 1901, o Instituto Agronômico de Campinas promoveu a primeira distribuição de sementes de soja para produtores paulistas e, nessa mesma data, têm-se registro do primeiro cultivo de soja no Rio Grande do Sul (EMBRAPA, 2004).

A partir dos anos 1980, a soja estendeu-se para o cerrado, área que compreende o Triângulo Mineiro, Mato Grosso do Sul, Mato Grosso, Goiás, Tocantins, sul do Maranhão, 
sul do Piauí e oeste da Bahia. Com isso, a região do cerrado tornou-se a maior região produtora de soja do país. A expansão para essa nova fronteira agrícola deveu-se, basicamente, aos estudos de fertilização dos solos do cerrado e a utilização de bactérias fixadoras de nitrogênio que permitiu a redução de gastos com adubação, à sua topografia plana e favorável à mecanização, e o desenvolvimento de plantas adaptadas à região (CISOJA, 2009). A soja é hoje a cultura com maior área cultivada e produção no Brasil em decorrência do bom preço dessa commodity nas últimas safras e do desenvolvimento de tecnologias para a cultura. Estima-se que, na safra 2014/15, a soja foi cultivada em 31 milhões de hectares, alcançando uma produção de 95,8 milhões de toneladas (CONAB, 2014).

No oeste da Bahia a cultura registrou avanço superior a $50 \%$ em área durante os últimos 10 anos e, na última safra, expandiu em mais $4,35 \%$ o espaço cultivado, que agora passa de 1,3 milhão de hectares. Já a produção do grão atingiu 3,3 milhões de toneladas (22\% a mais do que no ano anterior) e gerou receita de quase $\mathrm{R} \$ 2,5$ bilhões ( $28 \%$ a mais). Merece destaque, o crescente espaço dedicado à produção de sementes, que chegou a 160 mil hectares na safra 2013/14, enquanto na temporada anterior estava em cerca de 100 mil hectares, o total produzido em sementes de soja chegou em 2014 a cerca de 290 mil toneladas, das quais em torno de $30 \%$ permanecem na região e o restante é destinado a outras áreas produtoras (AIBA, 2014).

O sucesso da sojicultura na Bahia se deve também às pesquisas de cultivares mais produtivas e com características de resistência a diversas doenças. A Embrapa (Empresa Brasileira de Pesquisa Agropecuária), em parceria com a Fundação Bahia lançou para safra 2011/2012 as cultivares de soja BRS 313, BRS 314 e BRS 315 RR no oeste da Bahia com resistência moderada aos nematoides de galha (BRS 313), já a BRS 314 não apresenta resistência específica, a BRS 315 RR (transgênica) possui resistência ao glifosato (MOREIRA \& PIPOLO, 2011). Para a safra 2014/2015 foram lançadas as cultivares BRS Corisco com 
resistência a Meloidogyne javanica, BRS Barreiras suscetível às principais espécies de fitonematoides que afetam a soja ( $M$. javanica, $M$. incognita e Heterodera glycines). As cultivares BRS 7980 com resistência aos nematoides Heterodera glycines (raças 1, 3 e 5), aos nematoides Meloidogyne javanica e Meloidogyne incognita e a (Pratylenchus spp.), a BRS 8180RR que é resistente a $M$. incognita e moderadamente resistente a $M$. javanica. e BRS8280RR é resistente a $M$. incognita e moderadamente resistente a $M$. javanica (EMBRAPA, 2014).

\subsection{CULTURA DO ALGODÃO}

O algodão, Gossypium hirsutum L. é uma fibra natural, de origem vegetal, de comprimento variando entre 24 e $38 \mathrm{~mm}$ e é considerada a mais importante das fibras têxteis, além da fibra, o algodoeiro também produz óleo e proteína, esta podendo ser utilizada como suplemento protéico na alimentação animal e humana. (LUNARDON, 2007).

O algodão já era conhecido na China de três mil a.C. e era cultivado na Índia em 1.500 a.C., foi introduzido na Grécia e em Malta por Alexandre, o Grande (356 a.C. - 323 a.C.) e no século X os árabes o levaram para a Espanha e a Sicília. No Brasil, quando da chegada dos colonizadores portugueses, em 1500, o algodão já era cultivado pelos índios que o convertiam em fios e tecidos para diversas finalidades, nessa época no Brasil se cultivava o algodão arbóreo, de ciclo perene, e no século XIX, foi introduzido o algodão herbáceo, de ciclo anual e fibra curta (RODRIGUES \& BUENO, 2004; LUNARDON, 2007).

O algodão é cultivado em mais de 60 países. Os três maiores produtores são: China, Índia e Estados Unidos que, juntos, produzem $64 \%$ da produção mundial. A Índia, apesar de possuir área plantada maior, produz um volume de fibras quase igual ao dos Estados Unidos, isso em razão do baixo rendimento de suas lavouras. Completam a lista dos cinco maiores produtores, o Paquistão e o Brasil. Nos últimos anos, o Brasil melhorou sua colocação no ranking dos 
países produtores, atualmente, somos o quinto maior produtor mundial (ABRAPA, 2015). Na safra 2013/14 foram cultivados 1,12 milhões de hectares com a cultura do algodão no Brasil. Esta área supera em $20,2 \%$ a safra anterior. O aumento na produção foi ainda mais significativo, passando de 1.290.400 t de pluma, em 2012/13, para 1.734.200 t, em 2013/14 (CONAB, 2014).

Embora o algodão tenha sido, na última safra, cultivado em 15 estados do Brasil, 85\% da área plantada se concentra em Mato Grosso e Bahia, que assumiram o lugar de São Paulo e Paraná, principais produtores de algodão no inicio da cotonicultura no Brasil (LUNARDON, 2007; CONAB, 2014). A atividade, que tinha como característica a mão de obra familiar e era conduzida de forma manual, transformou-se em um grande empreendimento, com extensas lavouras, sofisticado maquinário e modernas usinas de beneficiamento. O algodão mudou o cenário do Centro-Oeste e Oeste da Bahia, na maior região de cultivo no país, o plantio é conduzido por grandes produtores e/ou grandes grupos empresariais, com alta tecnologia e investimentos. A Bahia, segundo maior produtor nacional, que responde por $28,48 \%$ da área total de algodão no país, ocupou na safra 2013/2014 área de 319,4 mil hectares, a produtividade média foi de $3.870 \mathrm{~kg} / \mathrm{ha}$, sendo que $96 \%$ da produção baiana é realizada no oeste do estado (AIBA, 2014; CONAB, 2014). As principais cultivares plantadas na região oeste da Bahia é a Delta Opal e Deltapine 4049, segundo Ribeiro (2005), tal cultivar apresenta características de adaptabilidade às condições climáticas da região, alta produtividade e resistência a doenças viróticas, porém são suscetíveis a moderadamente suscetíveis ao ataque de nematoides.

\subsection{CULTURA DO CAFÉ}

O cafeeiro é uma planta perene da família Rubiaceae. Das espécies do gênero Coffea, em número aproximado de 80, apenas $C$. arabica L. e $C$. canephora Pierre são cultivados 
comercialmente, sendo a primeira responsável por 70 a $80 \%$ do café comercializado no mundo (GONÇALVES \& SILVAROLA, 2001).

O cafeeiro é originário do continente africano, mais especificamente da Etiópia, mas foi através das Guianas que chegou ao norte do Brasil por volta de 1727, o primeiro plantio foi realizado na cidade de Belém do Pará, e posteriormente transferido para o Rio de Janeiro onde expandiu sua área chegando até o vale do Paraíba, avançando para o estado de São Paulo, e mais tarde para o norte do Paraná que por muito tempo foram os principais estados produtores (SAES E NAKAZONE, 2004).

Em determinado momento, o café se tornou o produto de maior peso e importância na economia brasileira, sendo o principal produto das exportações. Devido à adversidades climáticas em 1975, o norte do Paraná enfrentou dificuldades de manter a cultura que começou a conquistar novas fronteiras como o Minas Gerais, Bahia, Rondônia e Goiás (BRANDÃO, 2011).

Atualmente o Brasil é o maior produtor e exportador de café, com participação média de $25 \%$ nas exportações mundiais (MAPA, 2015). A produção brasileira está distribuída geograficamente em 15 Estados, onde o estado de Minas Gerais responde por aproximadamente 49,9\% da produção, seguido pelo Espírito Santo com 23,2\%, São Paulo com 10,1\%, Bahia com 5,2\%, Rondônia com 2,2\%, Paraná com 1,2\%, Goiás com $0,52 \%$, Mato Grosso com 0,37\%, Pará com 0,15\%, e outros com 0,29\% da produção (CONAB, 2014). Na Bahia a espécie mais cultivada é a arábica, sendo plantada no cerrado da região oeste e na região do planalto, na região do Atlântico é plantado principalmente o café conilon. A região oeste possui a menor área de cultivo de café do estado da Bahia, 11.214 hectares, porém devido aos investimentos em irrigação e pacote tecnológico de alto nível, conferiu as maiores produtividades do estado e do país. Na safra de 2014 a produtividade foi de 39,28 
sc/ha (CONAB, 2014). Sendo as cultivares Catuaí Vermelho, Catuaí Amarelo e Mundo Novo as mais plantadas no oeste baiano, segundo IAC (2015) essas cultivares estão entre as mais plantadas no Brasil e alguns países da América latina apresentando características de rusticidade, porte médio a baixo e alto no caso da cv. Mundo Novo, muito produtivas porém com suscetibilidade aos principais patógenos que afetam o cafeeiro.

\subsection{NEMATOIDES FITOPARASITAS}

Os nematoides constituem o mais abundante grupo de animais multicelulares em número de indivíduos no mundo, estimado em um milhão de espécies (VIGLIERCHIO, 1991). Os nematoides presentes no solo podem ser classificados em diferentes grupos tróficos, como proposto por Yeates et al. (1993), sendo os principais: fitoparasitas ou fitófagos, fungívoros ou micófagos, bacteriófagos, carnívoros ou predadores e onívoros. O potencial da agricultura mundial tem sido constantemente ameaçado pelo ataque de diversos organismos patogênicos e, os nematoides fitoparasitas estão entre as principais limitações ao aumento da produtividade agrícola em todo o mundo (CAMPOS, 1997; MOURA, 1997). As perdas devidas ao ataque de nematoides na agricultura mundial estão estimadas em aproximadamente, US\$ 80 bilhões anualmente (AGRIOS, 2005). Em termos gerais, a importância dos fitonematoides na produção agrícola é bastante variável e depende da espécie ou cultivar plantada, das condições edafoclimáticas das regiões de cultivo, das práticas culturais adotadas, do nível populacional e da espécie de nematoide presente (GOULART, 2008). Os fitonematoides são responsáveis por ações espoliadoras e tóxicas nas plantas hospedeiras, que direta ou indiretamente afetam os principais processos fisiológicos como respiração, fotossíntese, absorção e translocação de água e nutrientes e balanço hormonal (AGRIOS, 2005).

O tipo de vegetação exerce inegável influência sobre a prevalência de determinados nematoides em uma dada região (MATTOS et al., 2006). Segundo Cares e Huang (1991), as 
comunidades de nematoides são mais complexas em ecossistemas naturais do que em ecossistemas cultivados. Zamith e Lordello (1957) citados por Carvalho et al. (2010) observaram que os solos não alterados encerravam uma fauna de nematoides com número superior de gêneros e espécies, ao se utilizar tais áreas para o cultivo, verificava-se a eliminação de alguns nematoides e a permanência de outros, sendo observada também a introdução de alguns nematoides por meio de material vegetal infestado ou por máquinas e implementos agrícolas.

\subsubsection{NEMATOIDES NO CERRADO}

Em cerrado stricto sensu são encontrados com mais frequência nematoides dos gêneros Aorolaimus, Sher, 1963, Coslenchus Siddiqi, 1978, Criconema Hoffmanner e Menzel, 1914, Discocriconemella De Grisse e Loof, 1965, Hemicriconemoides Siddiqi, 1961 e Trophotylenchulus Raski, 1957. Os nematoides pertencentes aos gêneros Meloidogyne Goeldi, 1892, Hemicycliophora de Man, 1921, Aphelenchoides, Fischer, 1894 Malenchus Andrassy, 1968, Helicotylenchus Steiner, 1945 e Ditylenchus Filipjev, 1936 prevalecem em mata de galeria; em campos úmidos espécimes de Caloosia Siddiqi e Goodey, 1964, Criconemella De Grisse e Loof, 1965, Filenchus Andrassy, 1954, Pratylenchus Filipjev, 1936, Xiphinema Cobb, 1913 e Meloidogyne também foram encontrados (CARES \& HUANG, 1991). Huang e Cupertino (1976) relataram a ocorrência de Aphelenchus Bastian, 1865, Aphelenchoides, Helicotylenchus Steiner, 1945, Meloidogyne, Rotylenchus Filipjev, 1936 e Tylenchus Bastian, 1865, como os mais frequentemente encontrados em áreas que sofreram antropização, na região dos cerrados em Brasília. Em estudo das variações nas comunidades de nematoides ocorridas ao longo do ano no Cerrado, Carvalho et al. (2010) encontraram no verão: Aphelenchoides, Peltamigratus, Hemicycliophora, Panagrolainus, Helycotylenchus, Acrobeles e Meloidogyne, e na primavera: Malenchus, Seinura Fuchs, 1931, Pratylenchus, Tylencorhynchus Cobb, 1913, Gracilacus Raski, 1962 e Helycotylenchus. 
Goulart et al., 2008 comparando diferentes sistemas de lavoura-pecuária e cerrado preservado, encontraram exclusivamente nas áreas de cerrado os gêneros Paratylenchus Micoletzky, 1922 e Criconemella, sendo que Pratylenchus esteve presente em todos os tratamentos exceto em vegetação nativa do cerrado e Paratrichodorus Siddiqi, 1974, não foi encontrado em vegetação nativa, embora ocorresse associado às culturas. Nematoides dos gêneros Rotylenchus, Xiphinema, Discocriconemella, Hemicriconemoides, Criconemoides Taylor, 1936 e Ogma Southern, 1914 foram os parasitas de plantas mais abundantes em cinco fitofisionomias de cerrado no Distrito Federal, com destaque para a superfamília Criconematoidae que prevaleceu em todas as fitofisionomias (RODRIGUES, 2011).

Estudos de diversidade de nematoides podem ser aplicados para se avaliar a qualidade ou sanidade de solos, com possibilidade de utilizar nematoides como bioindicadores na avaliação de impacto de atividades humanas que causam alterações ambientais, bem como na avaliação da sustentabilidade produtiva (Neher, 2001).

\subsubsection{NEMATOIDES EM CAFEEIRO}

A cultura do café no Brasil possui importante relação com a história da nematologia, quando o pesquisador suíço Emilio Goeldi, relatou grandes estragos causados pelo nematoide Meloidogyne exigua Goeldi, 1887 ao cafeeiro na então Província do Rio de Janeiro (MOURA \& MARANHÃO, 2004). Desde então, os nematoides tem sido relacionados com a decadência de regiões nobres da cafeicultura nos Estados do Rio de Janeiro, Paraná e São Paulo (SANTOS 1997). Por serem organismos microscópicos, os nematoides têm sido inadvertidamente disseminados por mudas e por movimentação de solo infestado, sendo de difícil erradicação uma vez que tenham sido introduzidos em uma área (GONÇALVES, 2000). De acordo com Huang e Cares (1995) a abundância de nematoides é grande em cultivos perenes, devido à grande biomassa formada pelas raízes. Até então, pelo menos 38 espécies, em 31 gêneros de fitonematoides, como Meloidogyne, Pratylenchus, 
Helicotylenchus, Xiphinema, têm sido encontrados associados a raízes de cafeeiros no Brasil (CAMPOS, 1997). A fauna nematológica é variável de região para região cafeeira, sendo que, as espécies do gênero Meloidogyne e Pratylenchus são as mais prejudiciais à cafeicultura brasileira devido à ampla distribuição geográfica e à intensidade dos danos que causam (GONÇALVES \& SILVAROLA, 2001).

Existem várias espécies de Meloidogyne que infectam o cafeeiro no mundo, sendo que apenas M. exigua, M. javanica (Treub, 1885) Chitwood, 1949, M. hapla Chitwood, 1949 M. incognita, M. paranaensis Carneiro et al. 1996 e M. coffeicola Lordello e Zamith, 1960 já foram encontradas associadas à cultura no Brasil (GONÇALVES \& SILVAROLA, 2001). As perdas provocadas pelo nematoide das galhas podem variar desde a redução da produtividade das culturas, até levar as plantas à morte, como no caso de $M$. paranaensis, espécie descrita no Estado do Paraná (SILVA et al., 2006). Segundo Lordello (1984), dentre os danos causados ao sistema radicular incluem-se galhas fendilhamentos e escamações no tecido cortical, que chegam a causar total desorganização deste tecido, podendo ocorrer redução no sistema radicular. $\mathrm{Na}$ parte aérea, os sintomas incluem declínio, desfolha e clorose. Dependendo das condições climáticas locais, a planta estressada pode definhar.

Pelo menos cinco espécies de Pratylenchus, parasitam o cafeeiro, sendo importantes no Brasil P. coffeae (Zimmermann, 1898) Filipjev e Stekhoven, 1941 e P. brachyurus (OLIVEIRA et al., 1999). A espécie de Pratylenchus mais frequentemente associada ao cafeeiro é $P$. brachyurus, mas geralmente ocorre em baixas densidades populacionais e danos somente são observados em cafezais jovens, implantados sobre antigas áreas de pastagens ou nas quais gramíneas eram utilizadas como cobertura vegetal. Experimentos caracterizaram o cafeeiro como intolerante a $P$. brachyurus devido a sua baixa taxa de reprodução nessa hospedeira (INOMOTO et al., 1998). O nematoide das lesões do cafeeiro, $P$. coffeae, quando 
presente em uma área, ocorre geralmente em altas densidades, causando danos mais pronunciados que a primeira espécie (INOMOTO et al., 2007b).

\subsubsection{NEMATOIDES EM ALGODOEIRO}

Diferentes espécies de nematoides tem sido identificadas parasitando a cultura do algodoeiro, porém nem sempre causando danos a essa planta. As espécies mais comumente consideradas patogênicas ao algodoeiro são: Meloidogyne incognita e M. acronea Coetzee, 1956 (nematóides das galhas radiculares), Rotylenchulus reniformis (nematoide reniforme), Pratylenchus brachyurus (nematoide das lesões radiculares), Hoplolaimus spp. von Daday, 1905, Belonolaimus longicaudatus Rau, 1958. No Brasil, os nematoides mais comuns são: Meloidogyne incognita, Rotylenchulus reniformis e Pratylenchus brachyurus (BRIDGE, 1992; INOMOTO, 2001).

Durante o parasitismo, o Meloidogyne spp. induz a formação de galhas no sistema radicular da planta hospedeira, resultado da ação de enzimas que levam à hiperplasia e hipertrofia das células que auxiliam na sua alimentação. Em consequência da formação das galhas, ocorre uma redução na translocação de água e nutrientes das raízes para as folhas, refletindo em sintomas na parte aérea da planta. Esses sintomas podem ser agravados com o aumento da população de nematoides no solo e pela associação a outros patógenos como os fungos e bactérias, além do grau de sensibilidade da variedade cultivada à infecção por nematoides (ASMUS, 2001; DIAS et al., 2010). No Brasil, $M$. incognita tem ocorrência generalizada, estando distribuída praticamente por toda região produtora de algodão do país. Os danos causados por esse nematoide são maiores em solos de textura arenosa, com baixa fertilidade e quando se encontra em associação com o agente causador da murcha do algodoeiro, Fusarium oxysporum f. sp. vasinfectum Snyder \& Hansen, formando o complexo Fusarium x nematoide (SILVA et al. 2004).

A espécie Rotylenchulus reniformis, inicia sua infecção com as fêmeas imaturas após a última ecdise, e desta ação são observadas necrose no floema e no parênquima das raízes, o que 
resulta em uma redução do sistema radicular e afeta diretamente o desenvolvimento das plantas e a translocação de água e nutrientes para as folhas (INOMOTO et al., 2007). As plantas hospedeiras deste nematoide mostram-se mais baixas que o normal, com uma coloração que lembra sintomas de deficiência nutricional, e raízes, mesmo quando lavadas, apresentam-se com forte aderência de solo sobre as massas de ovos (INOMOTO et al., 2007a). A importância do $R$. reniformis para agricultura tem crescido em virtude da sua ampla distribuição geográfica e da ocorrência de altas populações.

Pratylenchus brachyurus, é um nematoide endoparasita migrador que se alimenta do conteúdo das células e durante sua movimentação causa lesões nas raízes as quais podem favorecer a penetração de fungos e bactérias, agravando os problemas fitossanitários (TIHOHOD, 1993). Estas lesões reduzem o desenvolvimento e a produtividade das plantas e, a depender da intensidade da infecção, podem levar à morte (MACHADO et al., 2006). Dentre as principais espécies de nematoides que são parasitas do algodão, Pratylenchus brachyurus é a mais comum no Brasil. Em levantamento realizado em 18 municípios do estado do Mato Grosso, representando mais de 20 mil ha, $M$. incognita estava presente em apenas $4 \%$ das amostras, enquanto que $P$. brachyurus apresentou uma frequência de 94\% (SILVA et al., 2003). No estado de Mato Grosso do Sul, situação semelhante é encontrada (29, 19 e 59\% de frequência de $M$. incognita, $R$. reniformis e P. brachyurus, respectivamente, em 104 amostras) (COMUNELLO \& ASMUS, 2003). Em Goiás, de um total de 237 amostras de solo e de raízes, verificou-se $P$. brachyurus em todos os 10 municípios amostrados e em $79 \%$ das amostras (GIELFI et al., 2003). Meloidogyne incognita, Pratylenchus brachyurus e Rotylenchulus reniformis estavam presentes em cultivos de algodão nos municípios de Barreiras, São Desidério, Riachão das Neves e Formosa do Rio Preto ocorrendo com frequências respectivas de 41\%,67\%, 20\% das 169 amostras de solo coletadas no oeste da Bahia (MATOS et al., 2010). 
As perdas causadas por nematoides em algodoeiro são crescentes, chegando a $20-50 \%$ em áreas infestadas por $R$. reniformis (presente em cerca de $20 \%$ dos algodoais de Mato Grosso do Sul) e por Meloidogyne incognita (10 a 25\% dos algodoais de Mato Grosso do Sul, Goiás e Bahia) (MACHADO et al., 2006). Geralmente, predominam baixas populações de $P$. brachyurus no campo, com perdas difíceis de serem detectadas, provavelmente chegando a 10\%; quando existe a associação desse nematoide com $R$. reniformis ou $M$. incognita, entretanto, os danos são mais facilmente percebidos. Quando P. brachyurus encontra-se em associação com $M$. incognita ou $R$. reniformis o controle desses nematoides torna-se mais difícil, pois o primeiro limita ou diminui a efetividade do controle por cultivares resistentes ou rotação, pois somente existe resistência para as últimas duas espécies (ASMUS, 2004).

\subsubsection{NEMATOIDES NA CULTURA DA SOJA}

Os principais nematoides que causam perdas à cultura da soja no Brasil são: Heterodera glycines (nematoide-de-cisto-da-soja), M. javanica, M. arenaria (Neal, 1889) Chitwood, 1949 e $M$. incognita (nematoides-das-galhas), R. reniformis (nematoide-reniforme) e o $P$. brachyurus (nematoide-das-lesões).

O nematoide-de-cisto-da-soja (NCS), H. glycines, atualmente ocorre em mais de 3 milhões de hectares cultivados com soja, causando reboleiras de plantas amareladas e subdesenvolvidas. É muito comum nos estados do Mato Grosso, Mato Grosso do Sul, Goiás e Minas Gerais, mas também ocorrem no Rio Grande do Sul, Paraná, São Paulo e Tocantins. (EMBRAPA, 2011). No Brasil, a raça predominante é a 3, embora as raças $1,2,4,4^{+}, 5$, 6,9,10,14 e $14^{+}$também já tenham sido identificadas (SILVA et al., 2003). Dias et al. (2004) encontraram a raça 3 de $H$. glycines em amostras de soja coletadas no município de Formosa do Rio Preto no oeste da Bahia. 
Nas áreas onde este nematoide é encontrado, ocorrem perdas na produção que chegam a 100\% dependendo do nível de infestação (MENDES \& DICKSON, 1993). Entre os nematoides de galhas, $M$. incognita e $M$. javanica são as espécies mais importantes para a cultura da soja no Brasil. M. javanica tem ocorrência generalizada, nos estados do Mato Grosso, Mato Grosso do Sul, Goiás, Minas Gerais e Bahia, exceto nas áreas cultivadas anteriormente com café ou algodão nas quais predomina $M$. incognita. Nos estados do Paraná, São Paulo e Maranhão, M. javanica e $M$. incognita ocorrem em proporções semelhantes (ASMUS, 2001; DIAS et al. 2010).

Os sintomas na parte aérea da planta causados por Meloidogyne spp. são semelhantes aos provocados por Heterodera glycines, mas que aparecem mais tarde, a partir da floração, geralmente o amarelecimento foliar causado pelos nematoides-das-galhas apresenta padrão internerval, enquanto o causado pelo nematoide-de-cisto é uniforme na folha. Porém, a principal diferença está nas raízes, que apresentam crescimento anômalo - as galhas - em número e tamanho variáveis no caso de Meloidogyne, ou subdesenvolvimento associado à presença de fêmeas obesas esbranquiçadas presas às raízes no caso de $H$. glycines (CUNHA et al., 2008; HENNING et al., 2014).

O nematoide-reniforme atualmente causa preocupação no centro-sul de Mato Grosso do Sul. É necessário cuidado para identificar os sintomas causados por $R$. reniformis pois as reboleiras são grandes, difíceis de serem percebidas por um observador desatento, e as plantas ficam menores, mas sem amarelecimento. As raízes não apresentam nem galhas nem fêmeas visíveis à vista desarmada, mas têm a tendência a manter mais argila aderida à sua superfície. Perdas de 10 a 30\% têm sido verificadas em soja cultivada em solos médio-argilosos (25-35\% de argila), situação que favorece esse nematoide (DIAS et al. 2010). 
O nematoide-das-lesões $P$. brachyurus, é mais frequente que qualquer uma das espécies acima citadas, mas geralmente ocorre em populações muito baixas. No estado de Mato Grosso e no norte de Mato Grosso do Sul, a existência de fatores favoráveis a ele solos de textura média-arenosa (15-25\% de argila), sequências de culturas suscetíveis (soja, milho e algodão) - levou ao aparecimento de populações elevadas. Quando é o único nematoide presente, tem causado perdas da ordem de 10 a $25 \%$. Outras vezes ocorre juntamente com o nematoide-de-cisto ou os nematoides-das-galhas, contribuindo para aumentar as perdas causadas pelos mesmos (FERRAZ, 1995; RIBEIRO, 2009). 


\section{MATERIAL E MÉTODOS}

\subsection{ESCOLHA DOS PONTOS DE COLETA}

Amostras de solo e raízes foram coletadas no período de janeiro a abril de 2014 (época em que as culturas anuais estão presentes no campo) nos principais municípios produtores de soja, algodão e café do oeste baiano sendo estes: São Desidério, Luiz Eduardo Magalhães, Barreiras, Formosa do Rio Preto, Riachão das Neves e Baianópolis. As fazendas amostradas foram escolhidas para representar as áreas produtoras das culturas de soja, algodão, café e de vegetação nativa de cerrado (que de agora em diante será referida somente como cerrado), as amostras de cerrado foram coletadas em áreas de reserva legal das fazendas.

Todo o café da região oeste da Bahia é cultivado com irrigação, principalmente com o sistema de pivô central, e as culturas anuais (soja e algodão) frequentemente são cultivadas dentro de uma mesma fazenda, sendo assim, um total de 30 fazendas foi amostrado, 15 somente de plantios de café, e 15 das culturas soja e algodão e de cerrado. As amostras em áreas de plantio de café foram coletadas nos municípios de Luiz Eduardo Magalhães, São Desidério e Barreiras onde se concentra a maioria das fazendas produtoras dessa cultura na região. As fazendas amostradas e os pontos de coleta georreferenciados estão representados no mapa, Figura 1. 


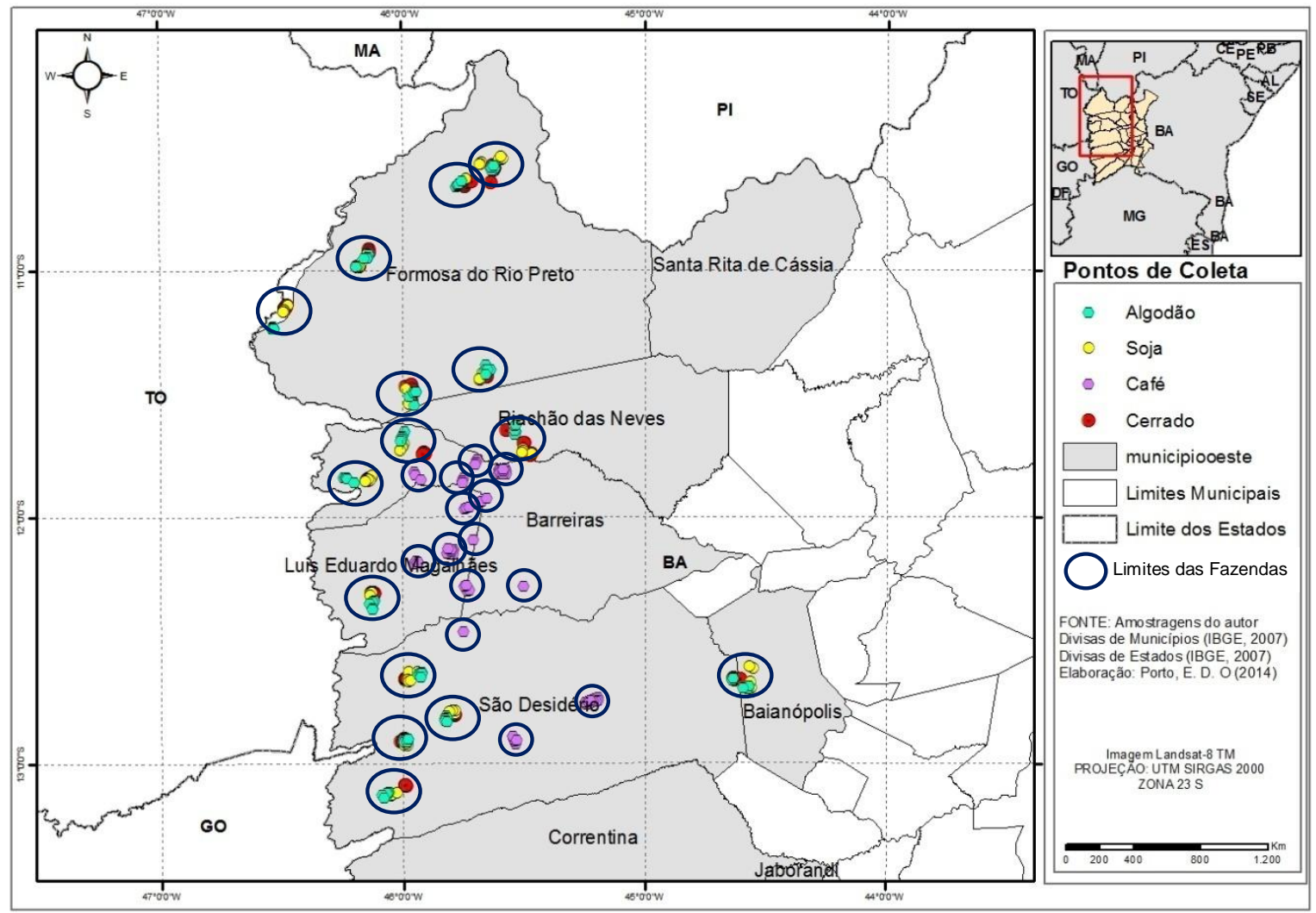

Figura 1: Pontos de coleta das amostras em áreas de soja, algodão, café e cerrado na região oeste da Bahia.

\subsection{AMOSTRAGEM}

Para amostragem nas culturas anuais e em cerrado, foram escolhidos em cada fazenda, cinco pontos de coleta em área com plantio de soja, cinco pontos de coleta em área de algodão e cinco pontos em área de cerrado (Figura 2) com base nas informações dadas pelos produtores quanto à presença de reboleiras nas plantações, quando tal informação não existia, os locais de coleta eram escolhidos aleatoriamente. Em cada ponto de coleta foi tomada uma amostra composta, para tal subamostras de solo mais o sistema radicular de 15 plantas distribuídas em 5 pontos (Figura 3A) foram retiradas na profundidade de zero a $20 \mathrm{~cm}$ com auxílio de enxadão, homegeneizadas e acondicionadas em sacos plásticos previamente identificados. Aproximadamente $7 \mathrm{~kg}$ de solo e raízes foram coletados para cada amostra composta. Nas fazendas produtoras de café, em cada pivô foram coletados solo e raízes em 8 pontos tomados ao longo da linha principal (Figura 3B) formando uma amostra composta por 
pivô. Foram coletadas 75 amostras compostas em cada cultura e no cerrado, totalizando 300 amostras compostas. As coordenadas dos locais de coleta foram marcadas com GPS modelo SMAP-60 CSx, Garmin com precisão de 2m.

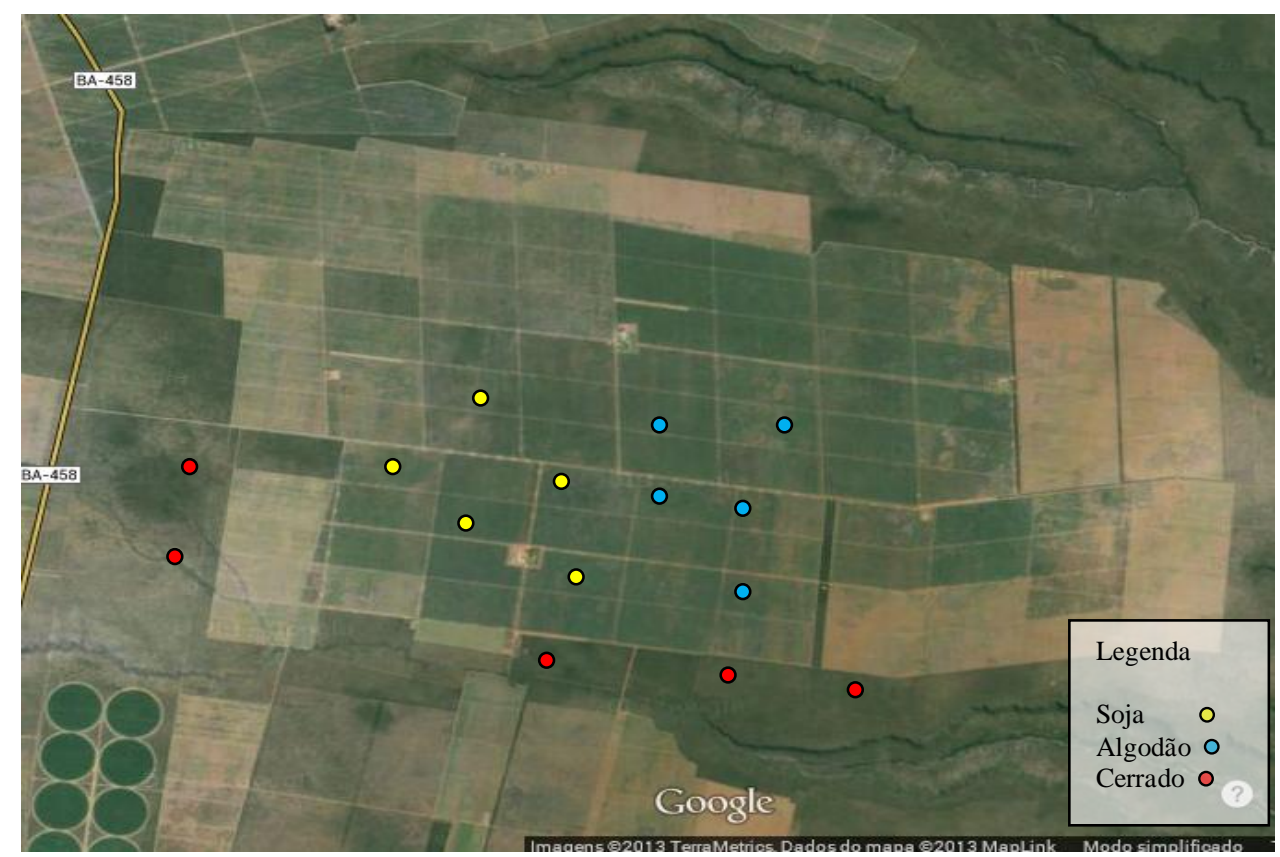

Figura 2. Esquema de amostragem aleatória de pontos de coleta em uma fazenda (áreas de plantio de soja, de algodão e no cerrado preservado).
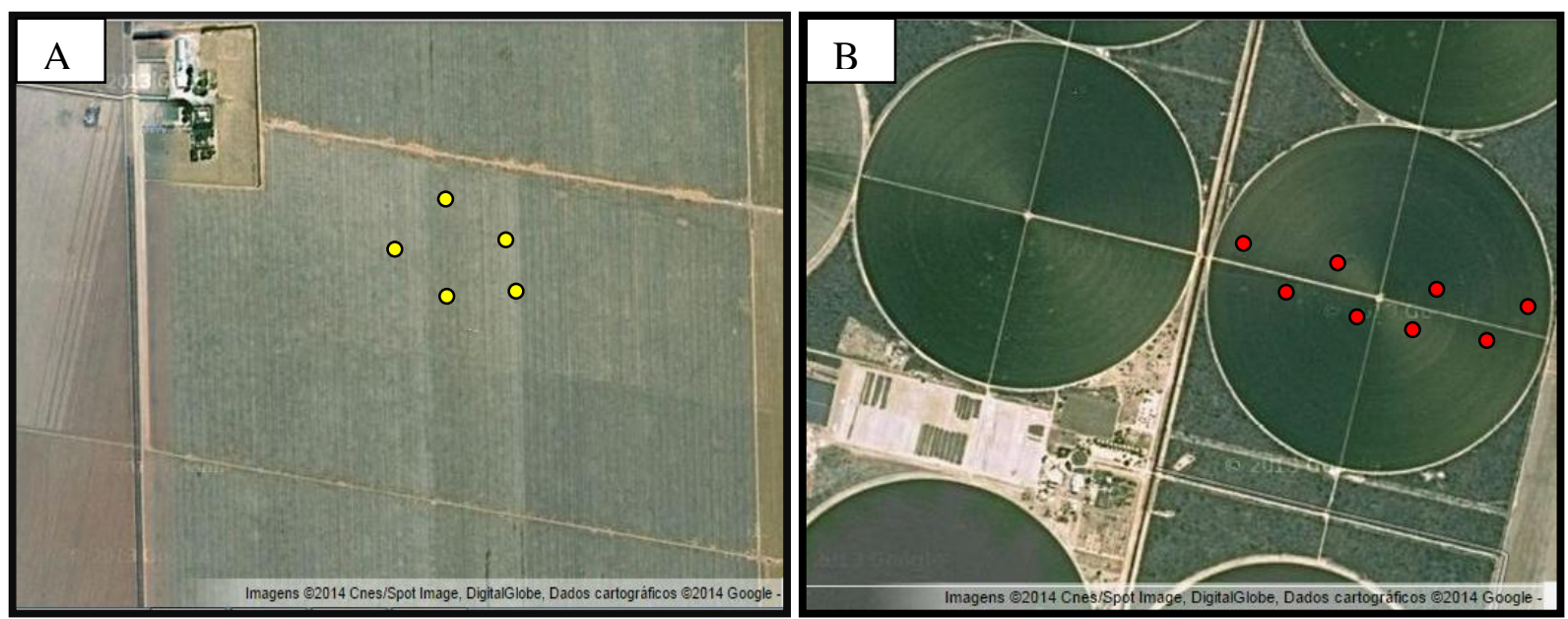

Figura 3. A: Amostragem em circulo em áreas de plantio de soja, algodão ou cerrado (5 subamostras/ 1 amostra composta). B: Esquema de amostragem em áreas de plantio de café com sistema de pivô central ( 8 subamostras/ 1 amostra composta). 


\subsection{MULTIPLICAÇÃO DAS POPULAÇÕES DE Meloidogyne spp.}

O solo de cada amostra composta foi homogeneizado, a maior parte das raízes e aproximadamente $500 \mathrm{~cm}^{3}$ do solo foram levados para o Laboratório de Nematologia da Universidade do Estado da Bahia Campus IX em Barreiras - BA, onde cada amostra foi processada para extração dos nematoides do solo e das raízes. O restante do solo foi colocado em vaso e neste, foram plantados dois tomateiros cv. Santa Cruz. As plantas foram mantidas nos vasos para que os nematoides presentes nas amostras se multiplicassem nos sistemas radiculares, que mais tarde foram removidos para a caracterização das populações de Meloidogyne spp. de acordo com a metodologia descrita por Carneiro e Almeida (2001) de fenótipos da enzima esterase (Est).

\subsection{PROCESSAMENTO DAS AMOSTRAS DE SOLO PARA QUANTIFICAÇÃO DOS NEMATOIDES}

Para a extração dos nematoides do solo, foram usados $300 \mathrm{~cm}^{3}$ do solo de cada amostra, colocado em balde contendo aproximadamente 2 litros de água; o solo foi destorroado manualmente e a suspensão agitada, após alguns segundos decantando a suspensão foi vertida em peneiras de $0,250 \mathrm{~mm}, 0,105 \mathrm{~mm}$ e $0,037 \mathrm{~mm}$ de abertura. $\mathrm{O}$ material retido na última peneira foi depositado em tubos para centrifuga de $50 \mathrm{ml}$ e submetido ao processo de clarificação por flotação centrífuga em sacarose (457g/1 litro de solução) e peneiramento segundo o método de Jenkins (1964).

\subsection{PROCESSAMENTO DAS AMOSTRAS DE RAIZ}

Foram pesados $10 \mathrm{~g}$ de raízes finas retiradas de diferentes sistemas radiculares de cada amostra. As raízes foram trituradas com água em liquidificador por 20 segundos, a suspensão foi vertida em peneiras com furos de 0,105 $\mathrm{mm}$ e $0,037 \mathrm{~mm}$ de abertura; o material retido na última peneira foi coletado em tubo de centrifuga no qual foi adicionado aproximadamente 1,5 g de caolin, sendo as amostras centrifugadas por $5 \mathrm{~min}$. a $3000 \mathrm{rpm}$, o sobrenadante foi 
descartado e ao sedimento foi adicionada solução de sacarose nos tubos que novamente foram submetidos à centrifugação por $1 \mathrm{~min}$. a $1500 \mathrm{rpm}$. Para remover a sacarose, os nematoides foram cuidadosamente lavados em água corrente na peneira de 0,037 mm. Após a extração, os nematoides provenientes do solo e das raízes foram mortos em banho-maria a $60{ }^{\circ} \mathrm{C}$ por 1 minuto e igual volume da solução fixadora (formalina, glicerina e água) de Golden (1965) duplamente concentrada foi adicionada à suspensão de nematoides.

\subsection{ANÁLISE DAS AMOSTRAS}

Os nematoides fixados foram levados para o Laboratório de Nematologia do Departamento de Fitopatologia da UnB, onde foi feita a identificação e contagem dos nematoides presentes, tanto nas amostras de solo como nas de raízes. As amostras foram colocadas para decantar em tubos de ensaio, o excesso de líquido foi retirado com auxilio de bomba de vácuo, concentradas ao volume de $4 \mathrm{ml}$. A leitura da amostra total foi realizada com auxilio de uma câmara de Peters. Os nematoides foram identificados a nível de gênero e suas respectivas populações foram quantificadas, em casos em que a quantidade de nematoides na amostra era muito elevada, foi realizada diluição e o valor final foi ajustado respeitando as devidas proporções. Para confirmação das espécies, as amostras foram infiltradas com glicerina pelo método de Seinhorst modificado por Cares e Huang (2008) e lâminas permanentes foram montadas para a visualização das estruturas nos aumentos de 400x e 1000x.

\subsection{IDENTIFICAÇÃO DE ESPÉCIES DE Meloidogyne}

Para identificar as espécies das populações de Meloidogyne, foi utilizado o Sistema Vertical de Eletroforese LCV 10x10 (Loccus-Biotecnologia), segundo metodologia descrita por Esbenshade e Triantaphillou (1990) e adaptada por Alonso e Alfenas (1998), com gel de poliacrilamida na concentração de 7,5\%. As raízes dos tomateiros contendo galhas foram retiradas dos vasos e lavadas. Para cada amostra, cinco fêmeas maduras foram extraídas com 
bisturi de cinco pontos diferentes do sistema radicular e colocadas cada uma em um tubo Ependorff de $500 \mu 1$, com $12 \mu 1$, de solução extratora (sacarose $25 \%$, Triton X-100 0,25\%, azul de bromofenol 0,01\% e água destilada), os tubos foram mantidos em caixa de isopor com gelo triturado durante todo o processo, as fêmeas foram trituradas inserindo um bastão de vidro de ponta esférica dentro dos tubos. O preparo do gel foi feito adicionando: tampão Tris-HCI 2,25 M (pH 8,8), solução de acrilamida, água destilada e TEMED. Imediatamente após o preparo, a solução foi vertida entre as placas de vidro da cuba de eletroforese que foi levada à geladeira para solidificação do gel e formação dos poços durante 15 minutos. A cuba foi preenchida com solução tampão do eletrodo e só então a as amostras foram depositadas cada uma em um poço do gel, como padrão de comparação utilizou-se fêmeas de $M$. javanica em uma das extremidades do gel. A corrida foi realizada a $200 \mathrm{~V}$ e $30 \mathrm{~mA}$, por 1 hora a $4^{\circ} \mathrm{C}$. Após esse período, o gel foi retirado das placas de vidro e colocado em solução corante (acetato $\alpha$-naftil e corante fast blue RR), e então incubado por aproximadamente 15 minutos a $30^{\circ} \mathrm{C}$ em estufa até o aparecimento das bandas, a solução corante foi então descartada e uma solução para a descoloração do gel foi adicionada. Posteriormente, o gel foi colocado sob luz branca, para ser fotografado. Os padrões de bandas obtidos foram comparados com os da Figura 4 (ESBENSHADE \& TRIANTAPHYLLOU, 1990; CARNEIRO \& ALMEIDA, 2000; CARNEIRO \& ALMEIDA, 2001; CARNEIRO \& COFCEWICZ, 2008). 


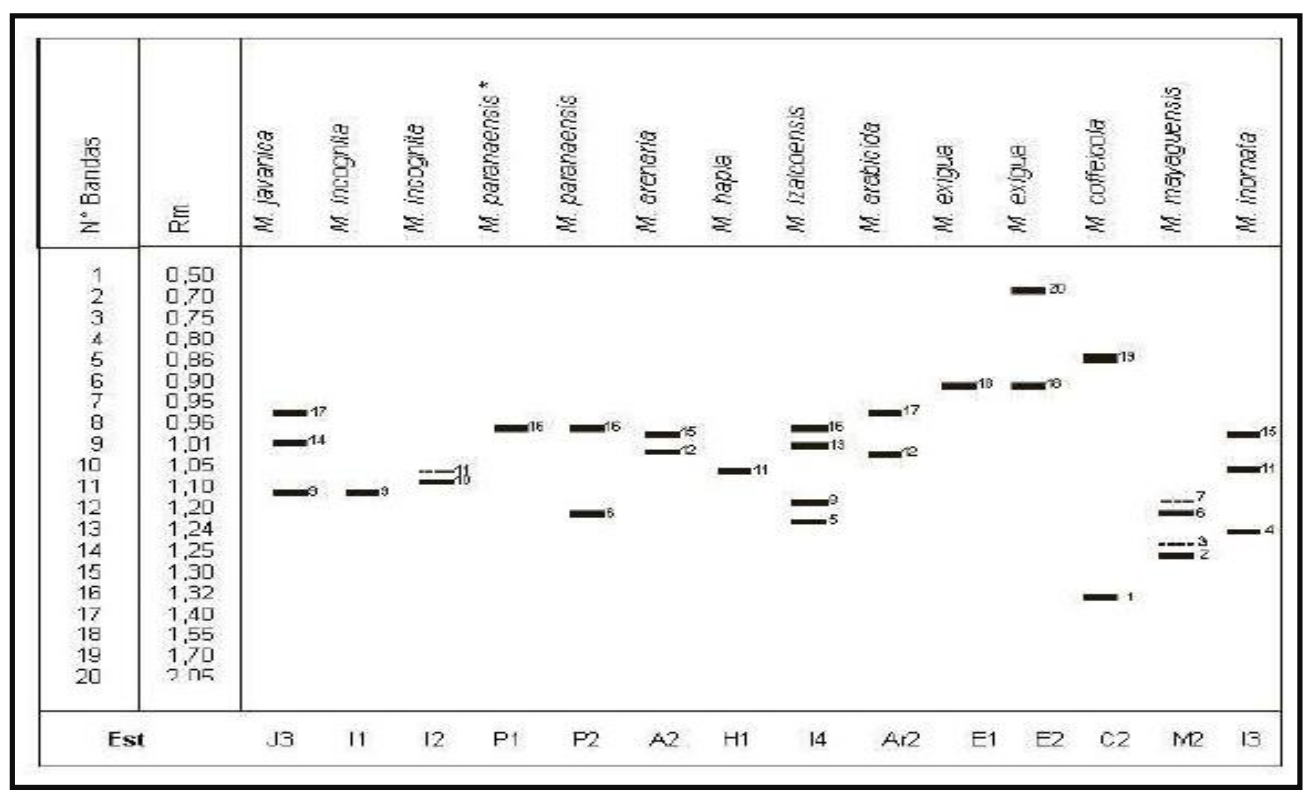

Figura 4: Padrões da isoenzima esterase para espécies de Meloidogyne (CARNEIRO \& COFCEWICZ, 2008).

\subsection{MONTAGEM DOS MAPAS DE DISTRIBUIÇÃO DE NEMATOIDES}

Os mapas da distribuição dos nematoides fitopatogênicos na região foram montados utilizando o software ArcGIS-10, através das coordenadas geográficas de cada ponto de coleta e dos valores de contagem de espécimes de cada gênero encontrados nas leituras das amostras. 


\section{RESULTADOS}

\subsection{NEMATOIDES FITOPARASITAS}

De acordo com a Tabela 1, espécimes do gênero encontrado com maior frequência nas amostras de solo foi Helicotylenchus (58,3\%), seguido de Pratylenchus $(52,3 \%)$, sendo que $P$. brachyurus foi encontrado em $96 \%$ das amostras que continham espécimes do gênero, e Heterodera glycines com a menor frequência nas amostras (3\%), vale salientar que este nematoide foi quantificado baseado somente na presença de juvenis de segundo estádio. Rotylenchulus reniformis teve maior frequência nas áreas de algodão (16\%), mas também ocorreu em soja e em cerrado, enquanto Hemicycliophora spp. apareceu somente em áreas de cultivo de café em $69,3 \%$ das amostras de solo. Também foram encontrados em menores quantidades espécimes de Scutellonema Andrassy, 1958, Hoplolaimus, Criconemoides, Discocriconemella, Nothocriconemoides Maas, Loof e De Grisse, 1971, Gracilacus, Paratrichodorus e Trichodorus Cobb, 1913, além de diversos nematoides bacteriófagos e micófagos e alguns predadores e onívoros.

Tabela 1. Frequência (\%) das populações de nematoides fitoparasitas encontrados em 75 amostras de solo e raízes para cada cultura e vegetação nativa de cerrado do oeste da Bahia.

\begin{tabular}{|c|c|c|c|c|c|c|c|c|c|c|}
\hline \multirow[t]{2}{*}{ GÊNEROS } & \multicolumn{2}{|c|}{ SOJA } & \multicolumn{2}{|c|}{ ALGODÃO } & \multicolumn{2}{|c|}{ CAFÉ } & \multicolumn{2}{|c|}{ CERRADO } & \multicolumn{2}{|c|}{ Total (300 amostras) } \\
\hline & SOLO & RAIZ & SOLO & RAIZ & SOLO & RAIZ & SOLO & RAIZ & SOLO & RAIZ \\
\hline Pratylenchus & 85,4 & 92 & 82,7 & 97,3 & 25,3 & 42,7 & 16 & 36 & 52,3 & 67 \\
\hline Meloidogyne & 18,7 & 14,7 & 18,7 & 24 & 28 & 24 & 50,7 & 29,3 & 29 & 23 \\
\hline Rotylenchulus & 9,3 & - & 16 & 9,3 & 4 & 2,7 & 13,3 & - & 10,3 & 3,3 \\
\hline Helicotylenchus & 65,3 & 60 & 84 & 74,6 & 42,7 & 33,3 & 41,3 & 26,7 & 58,3 & 48,7 \\
\hline Heterodera $(\mathrm{J} 2)$ & 6,7 & - & 4 & - & - & - & 1,3 & - & 3 & - \\
\hline Hemicycliophora & - & - & - & - & 69,3 & 33,3 & - & - & 17,3 & 8,3 \\
\hline Scutellonema & - & - & - & - & - & - & 8 & 2,7 & 2 & 0,7 \\
\hline Gracilacus & 2,7 & - & - & - & - & - & 13,3 & - & 4 & - \\
\hline Hoplolaimus & 2,7 & - & - & - & - & - & - & - & 0,7 & - \\
\hline Criconemoides & 14,7 & - & 9,3 & - & 16 & - & 57,3 & - & 24,3 & - \\
\hline Discocriconemella & - & - & 1,3 & - & - & - & 2,7 & - & 1 & - \\
\hline Nothocricomemoides & 1,3 & - & - & - & 2,7 & - & 13,3 & - & 4,3 & - \\
\hline Paratrichodorus & & - & 6,7 & - & - & - & - & - & 1,7 & - \\
\hline Trichodorus & 14,7 & - & 28 & - & 16 & - & 20 & - & 19,7 & - \\
\hline
\end{tabular}


Os valores mínimos e máximos de espécimes dos principais gêneros de nematoides fitoparasitas encontrados nas áreas de soja, algodão, café e cerrado para cada fazenda, estão expostos nas Tabelas 2-5.

Tabela 2: Valores mínimos e máximos das populações de nematoides fitoparasitas encontrados em amostras de $300 \mathrm{~cm}^{3}$ de solo e $10 \mathrm{~g}$ de raízes, coletadas em plantios de soja do oeste da Bahia.

\begin{tabular}{|c|c|c|c|c|c|c|c|c|}
\hline \multicolumn{9}{|c|}{ SOJA } \\
\hline \multirow[b]{2}{*}{ Fazendas } & \multicolumn{2}{|c|}{ Pratylenchus } & \multicolumn{2}{|c|}{ Meloidogyne } & \multicolumn{2}{|c|}{ Rotylenchulus } & \multicolumn{2}{|c|}{ Helicotylenchus } \\
\hline & SOLO & RAIZ & SOLO & RAIZ & SOLO & RAIZ & SOLO & RAIZ \\
\hline F2 (Formosa do Rio Preto) & $0-120$ & $4-584$ & 0 & 0 & $0-16$ & 0 & $0-1180$ & $0-68$ \\
\hline F3 (Barreiras) & $0-148$ & $16-880$ & 0 & $0-4$ & 0 & 0 & $0-502$ & $0-44$ \\
\hline F5 (Luiz E. Magalhães) & $16-280$ & $60-888$ & 0 & $0-9$ & 0 & 0 & $204-2016$ & $2-66$ \\
\hline F6 (São Desidério) & $0-108$ & $20-250$ & 0 & 0 & $0-102$ & 0 & $1-312$ & $0-50$ \\
\hline F7(São Desidério) & $20-134$ & $14-2024$ & $0-82$ & 0 & $0-20$ & 0 & $300-1300$ & $0-227$ \\
\hline F8 (São Desidério) & $0-108$ & $20-250$ & $0-156$ & $0-40$ & 0 & 0 & $212-5350$ & $0-742$ \\
\hline F9 (Baianópolis) & $2-211$ & $32-620$ & $0-5$ & 0 & 0 & 0 & $0-16$ & $0-10$ \\
\hline F13 (Formosa do Rio Preto) & $0-16$ & $0-464$ & $0-18$ & 0 & 0 & 0 & $0-14$ & $0-8$ \\
\hline F14 (Formosa do Rio Preto) & $2-328$ & $0-1298$ & $2-1404$ & $0-68$ & 0 & 0 & $0-436$ & $0-15$ \\
\hline F15 (Formosa do Rio Preto) & $11-152$ & $382-1984$ & 0 & 0 & $0-6$ & 0 & $0-12$ & $0-10$ \\
\hline
\end{tabular}


Tabela 3: Valores mínimos e máximos das populações de nematoides fitoparasitas encontrados em amostras de $300 \mathrm{~cm}^{3}$ de solo e $10 \mathrm{~g}$ de raízes, coletadas em plantios de algodão do oeste da Bahia.

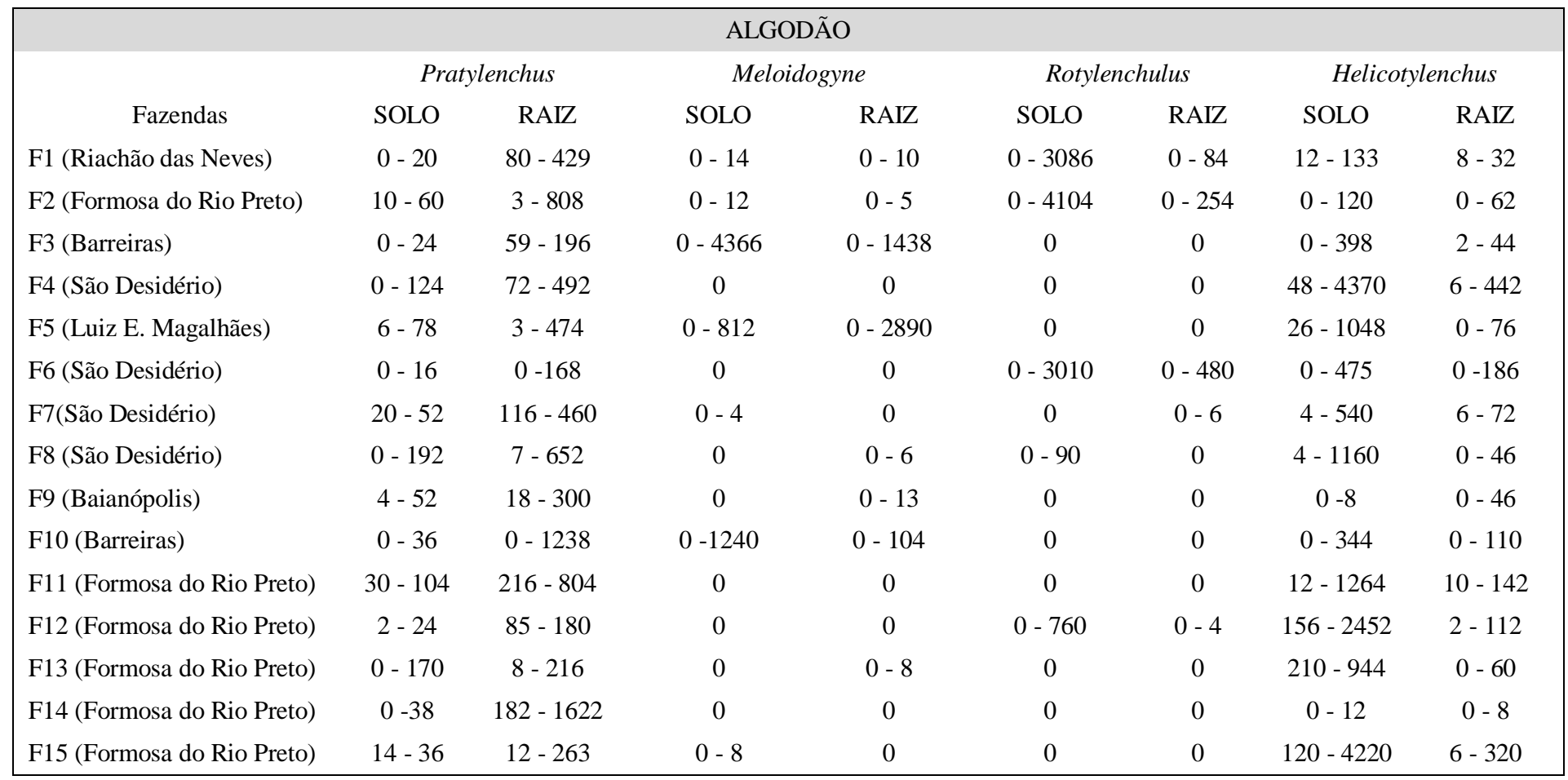

Tabela 4: Valores mínimos e máximos das populações de nematoides fitoparasitas encontrados em amostras de $300 \mathrm{~cm}^{3}$ de solo e $10 \mathrm{~g}$ de raízes, coletadas em plantios de café do oeste da Bahia.

\begin{tabular}{|c|c|c|c|c|c|c|c|c|}
\hline \multicolumn{9}{|c|}{ CAFÉ } \\
\hline & \multicolumn{2}{|c|}{ Pratylenchus } & \multicolumn{2}{|c|}{ Meloidogyne } & \multicolumn{2}{|c|}{ Helicotylenchus } & \multicolumn{2}{|c|}{ Hemicycliophora } \\
\hline Fazendas & SOLO & RAIZ & SOLO & RAIZ & SOLO & RAIZ & SOLO & RAIZ \\
\hline F16 (Luiz E. Magalhães) & $0-9$ & $0-5$ & $0-16$ & $0-5$ & $0-15$ & $0-63$ & $0-288$ & $0-11$ \\
\hline F17 (Luiz E. Magalhães) & $2-6$ & $0-4$ & $0-4$ & 0 & $0-42$ & $0-3$ & $2-22$ & 0 \\
\hline F18(Luiz E. Magalhães) & 0 & 0 & $0-1$ & $0-3$ & $0-3$ & $0-12$ & $0-10$ & 0 \\
\hline F19 (Barreiras) & $0-8$ & $0-8$ & $0-14$ & $0-76$ & $0-1$ & $0-1$ & $0-190$ & $0-6$ \\
\hline F20 (Barreiras) & $0-13$ & 0 & $0-10$ & $0-2$ & $0-5$ & $0-3$ & $0-30$ & 0 \\
\hline F21 (Barreiras) & 0 & $0-17$ & $0-61$ & $0-3$ & $0-44$ & $0-3$ & $22-155$ & $0-5$ \\
\hline F22 (São Desidério) & $0-6$ & $0-15$ & $0-77$ & $0-8$ & 0 & 0 & $32-175$ & 0 \\
\hline F23 (São Desidério) & 0 & 0 & 0 & 2 & 0 & 0 & 221 & 0 \\
\hline F24 (São Desidério) & $0-8$ & $0-32$ & $0-205$ & $0-101$ & $0-33$ & $0-17$ & $0-40$ & 0 \\
\hline F25 (Luiz E. Magalhães) & 0 & $0-7$ & $0-36$ & 0 & $0-5$ & $0-2$ & $0-446$ & $0-4$ \\
\hline F26 (Barreiras) & $0-6$ & $0-4$ & 0 & $0-6$ & $0-8$ & $0-2$ & $7-403$ & 0 \\
\hline F27 (Luiz E. Magalhães) & 0 & 0 & 0 & 0 & 0 & 0 & 0 & 0 \\
\hline F28 (Barreiras) & 0 & $0-12$ & 0 & 0 & 0 & 0 & $0-127$ & 0 \\
\hline F29 (Barreiras) & $0-5$ & $0-8$ & 0 & 0 & $0-8$ & 0 & 0 & 0 \\
\hline F30 (Barreiras) & $0-16$ & $0-72$ & $0-12$ & $0-36$ & $0-50$ & $0-15$ & $0-141$ & $0-12$ \\
\hline
\end{tabular}


Tabela 5: Valores mínimos e máximos das populações de nematoides fitoparasitas encontrados em amostras de $300 \mathrm{~cm}^{3}$ de solo e $10 \mathrm{~g}$ de raízes, coletadas em áreas de cerrado do oeste da Bahia.

\begin{tabular}{|c|c|c|c|c|c|c|c|c|}
\hline \multicolumn{9}{|c|}{ CERRADO } \\
\hline \multirow[b]{2}{*}{ Fazendas } & \multicolumn{2}{|c|}{ Pratylenchus } & \multicolumn{2}{|c|}{ Meloidogyne } & \multicolumn{2}{|c|}{ Rotylenchulus } & \multicolumn{2}{|c|}{ Helicotylenchus } \\
\hline & SOLO & RAIZ & SOLO & RAIZ & SOLO & RAIZ & SOLO & RAIZ \\
\hline F1 (Riachão das Neves) & 0 & $0-8$ & $0-14$ & $0-12$ & $0-68$ & 0 & $0-154$ & $0-6$ \\
\hline F2 (Formosa do Rio Preto) & $0-4$ & $0-50$ & $0-122$ & $0-108$ & 0 & 0 & $0-44$ & $0-5$ \\
\hline F3 (Barreiras) & 0 & $0-12$ & $0-65$ & $0-28$ & $0-2$ & 0 & $0-32$ & $0-4$ \\
\hline F4 (São Desidério) & $0-4$ & $0-94$ & 0 & $0-14$ & 0 & 0 & $0-4$ & $0-6$ \\
\hline F5 (Luiz E. Magalhães) & $0-22$ & $0-138$ & $0-87$ & $0-125$ & 0 & 0 & $0-14$ & $0-11$ \\
\hline F6 (São Desidério) & $0-16$ & $0-736$ & $0-88$ & $0-46$ & $0-23$ & 0 & $0-28$ & $0-12$ \\
\hline F7(São Desidério) & 0 & $0-6$ & $0-172$ & $0-6$ & $0-20$ & 0 & $0-8$ & 0 \\
\hline F8 (São Desidério) & 0 & $0-5$ & $0-613$ & $0-10$ & $0-121$ & 0 & $0-42$ & 0 \\
\hline F9 (Baianópolis) & 0 & $0-8$ & $0-20$ & $0-15$ & 0 & 0 & $0-243$ & $0-10$ \\
\hline F10 (Barreiras) & 0 & $0-12$ & $0-20$ & 0 & $0-40$ & 0 & $0-4$ & $0-2$ \\
\hline $\begin{array}{l}\text { F11 (Formosa do Rio } \\
\text { Preto) }\end{array}$ & $0-28$ & $0-104$ & $0-52$ & 0 & $0-28$ & 0 & $0-5$ & 0 \\
\hline $\begin{array}{l}\text { F12 (Formosa do Rio } \\
\text { Preto) }\end{array}$ & 0 & $0-176$ & $0-30$ & 0 & 0 & 0 & $0-48$ & $0-690$ \\
\hline $\begin{array}{l}\text { F13 (Formosa do Rio } \\
\text { Preto) }\end{array}$ & $0-8$ & $0-133$ & $0-15$ & 0 & $0-8$ & 0 & $0-3$ & $0-18$ \\
\hline $\begin{array}{l}\text { F14 (Formosa do Rio } \\
\text { Preto) }\end{array}$ & $0-4$ & $0-4$ & $0-24$ & $0-3$ & $0-1860$ & 0 & $0-47$ & $0-4$ \\
\hline $\begin{array}{l}\text { F15 (Formosa do Rio } \\
\text { Preto) }\end{array}$ & $0-5$ & $0-40$ & $0-300$ & $0-10$ & 0 & 0 & 0 & 0 \\
\hline
\end{tabular}

\subsection{POPULAÇÕES DE Meloidogyne spp.}

Das 300 amostras coletadas, 87 amostras de solo foram positivas para a presença de Meloidogyne spp. e destas, foi possível obter 53 populações do nematoide com a seguinte distribuição: 25 oriundas de plantios de café, 13 de plantios de soja, 11 de plantios de algodão e 4 de cerrado.

Os fenótipos da isoenzima esterase encontrados (EST) J3 e I1, (Figura 5) mostraram que $70 \%$ das populações de Meloidogyne obtidas continham a espécie $M$. javanica e $45 \%$ continham $M$. incognita, sendo $15 \%$ compostas pelas duas espécies. No café $M$. javanica estava presente em 92\% (23) das populações e $M$. incognita estava presente em $24 \%$ (6), sendo que duas populações eram compostas somente por M. incognita. Na soja, M. javanica estava presente em 77\% (10) das populações e M. incognita estava presente em 30,7\% (4), uma população era somente de $M$. incognita. No algodão, $100 \%$ pertenciam a $M$. incognita e 
nas populações do cerrado, uma era exclusivamente de $M$. javanica e as demais mistas de $M$. incognita e M. javanica.

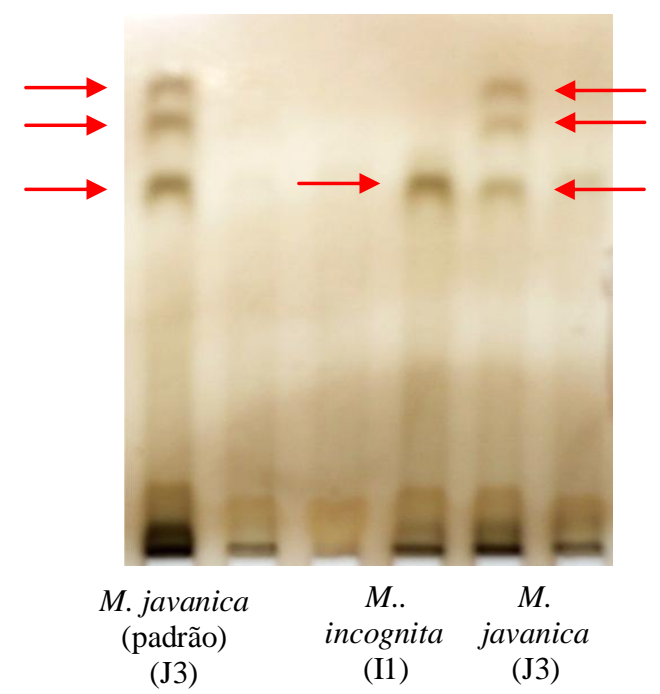

Figura 5: Padrões da isoenzima esterase encontrados nos géis de poliacrilamida para as espécies Meloidogyne incognita (I1) e M. javanica (J3) encontradas em amostras de solo coletadas no Oeste da Bahia.

\subsection{DISTRIBUIÇÃO DOS NEMATOIDES FITOPARASITAS}

Os mapas da distribuição de espécimes de cada gênero nas áreas amostradas revelam uma relativa uniformidade na presença de Pratylenchus spp., Meloidogyne spp., R. reniformis e Helicotylenchus spp. em toda a região oeste da Bahia (Figuras 6, 7, 8 e 9). Sendo Pratylenchus e Helicotylenchus os mais disseminados nos municípios, e apresentando menores variações populacionais nas áreas de coleta. Meloidogyne apresentaram os mais elevados níveis populacionais nos municípios de Barreiras, Luiz Eduardo Magalhães e Formosa do Rio Preto e Rotylenchus nos municípios de Riachão das Neves, São Desidério e Formosa do Rio Preto. Hemicycliophora ficou restrito aos municípios de Barreiras, Luiz Eduardo Magalhães, e São Desidério, já que espécimes desse gênero foram encontrados somente em áreas cultivadas com café (Figura 10). O nematoide $H$. glycines foi encontrado em poucas amostras e em níveis baixos neste levantamento, nos municípios de Barreiras, Formosa do Rio Preto e São Desidério (Figura11). 


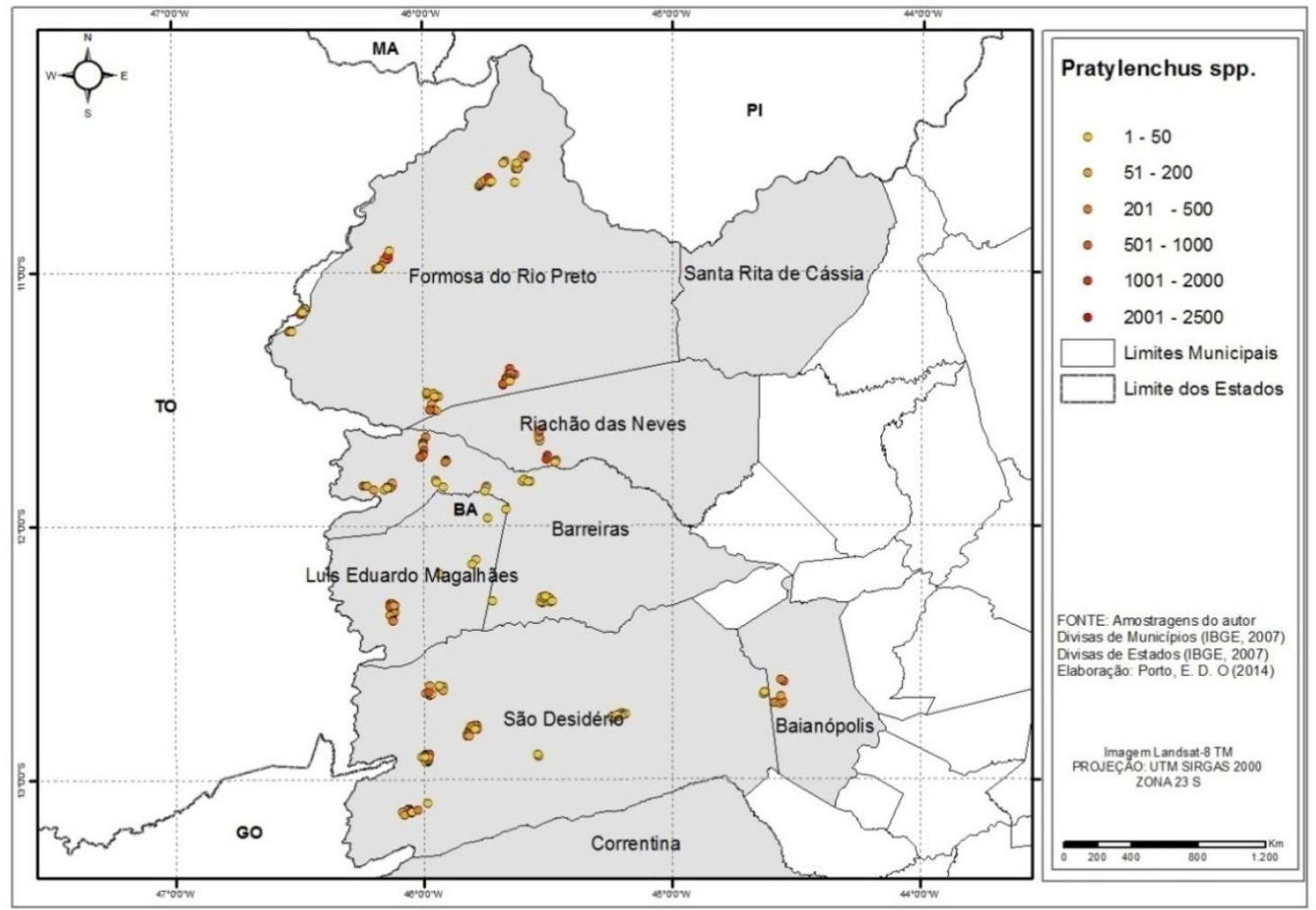

Figura 6: Mapa da distribuição de Pratylenchus spp. na região oeste da Bahia e os intervalos das populações encontradas em cada local de amostragem em $10 \mathrm{~g}$ de raizes.

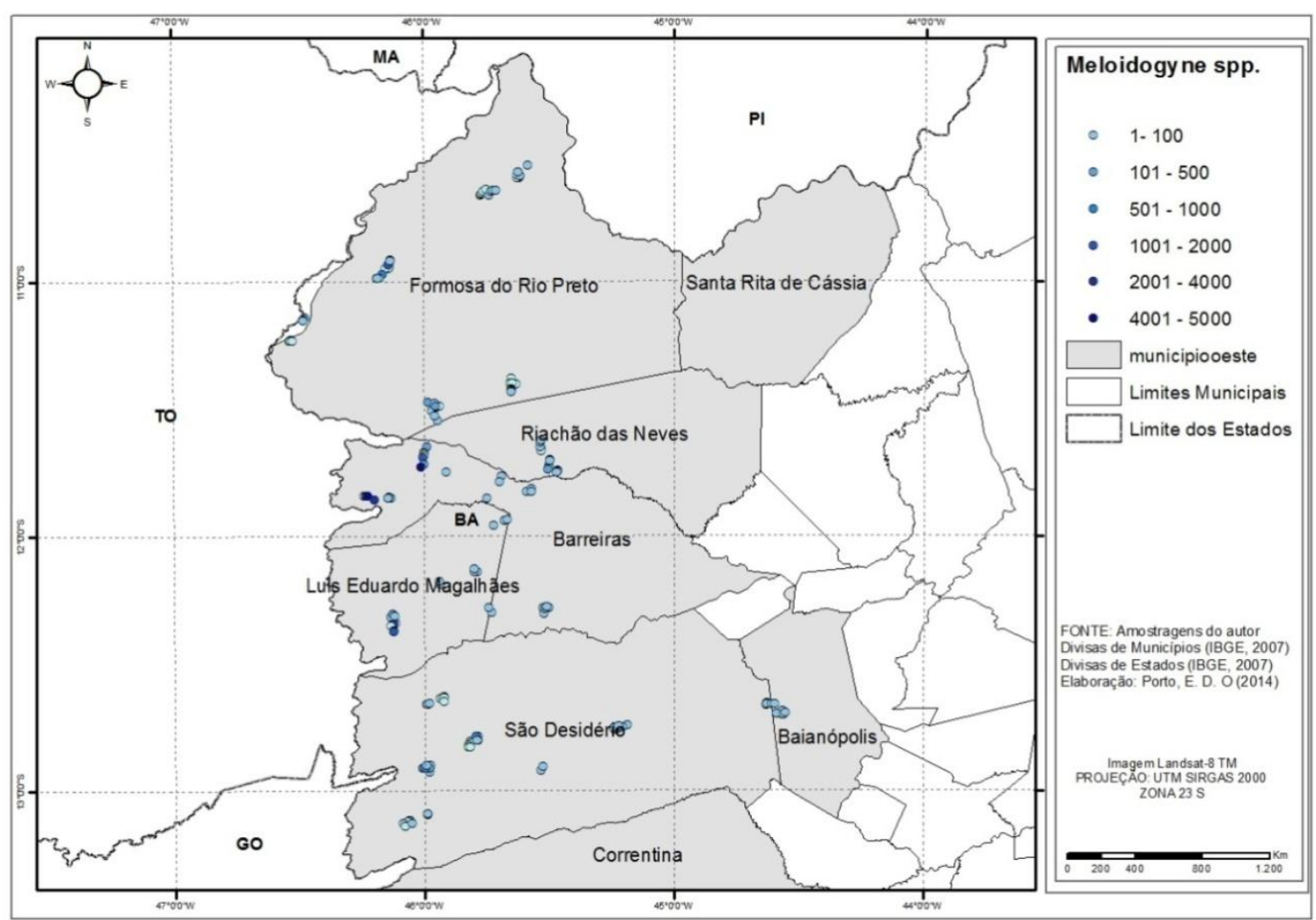

Figura 7: Mapa da distribuição de Meloidogyne spp. na região oeste da Bahia e os intervalos das populações encontradas em cada local de amostragem em $300 \mathrm{~cm}^{3}$ de solo. 


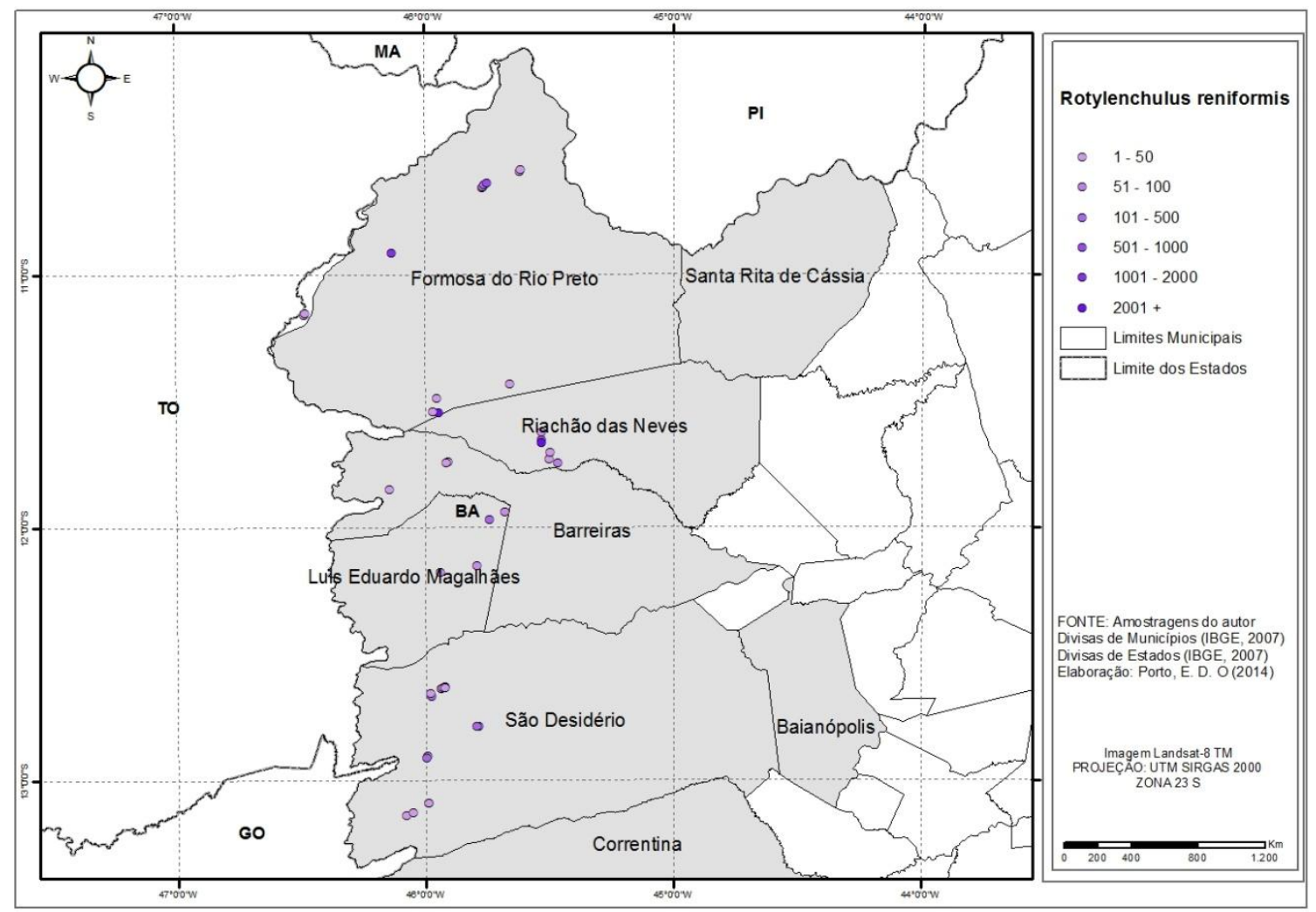

Figura 8: Mapa da distribuição de Rotylenchulus reniformis na região oeste da Bahia e os intervalos das populações encontradas em cada local de amostragem em $300 \mathrm{~cm}^{3}$ de solo.

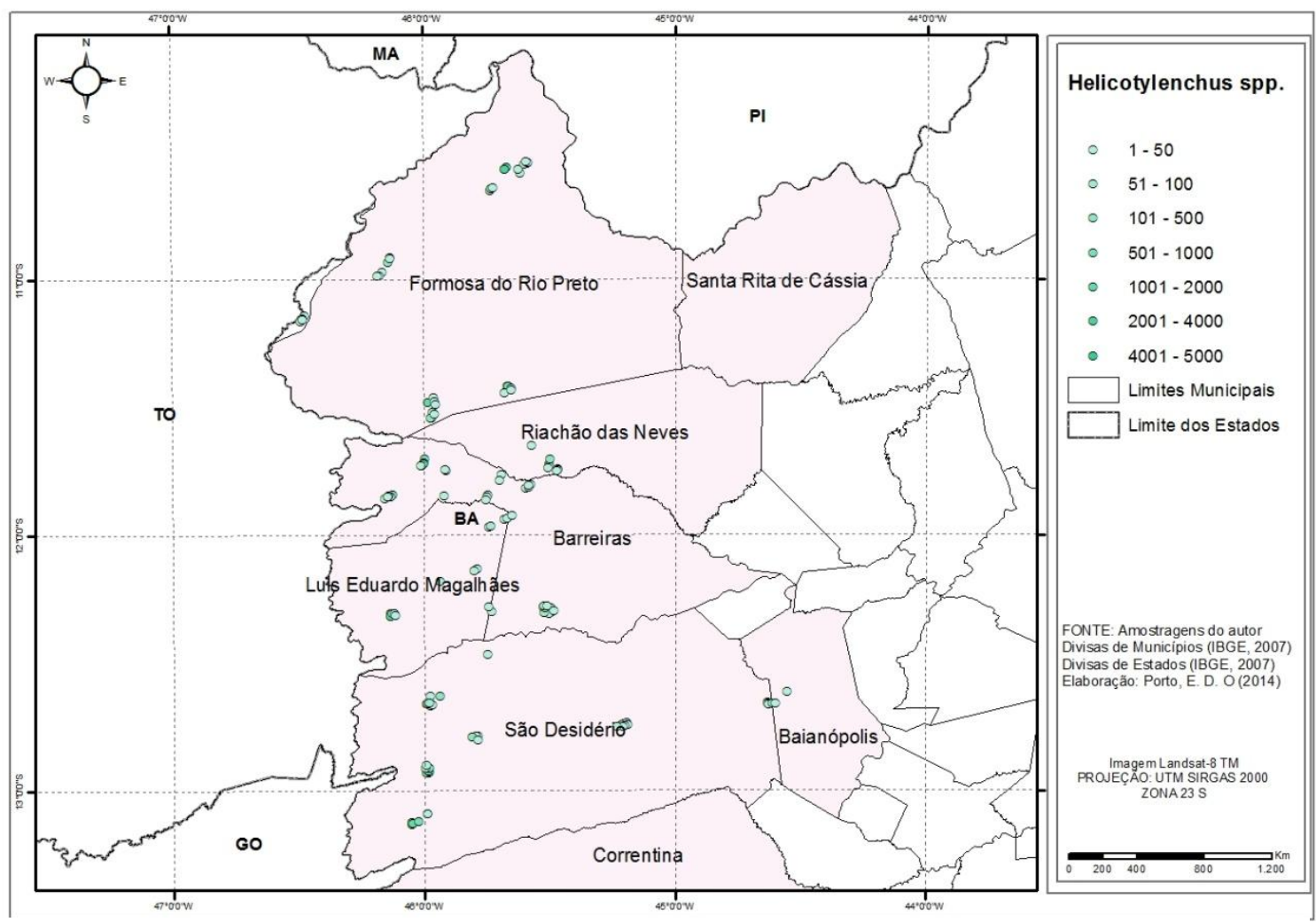

Figura 9: Mapa da distribuição de Helicotylenchus spp. na região oeste da Bahia e os intervalos das populações encontradas em cada local de amostragem em $300 \mathrm{~cm}^{3}$ de solo. 


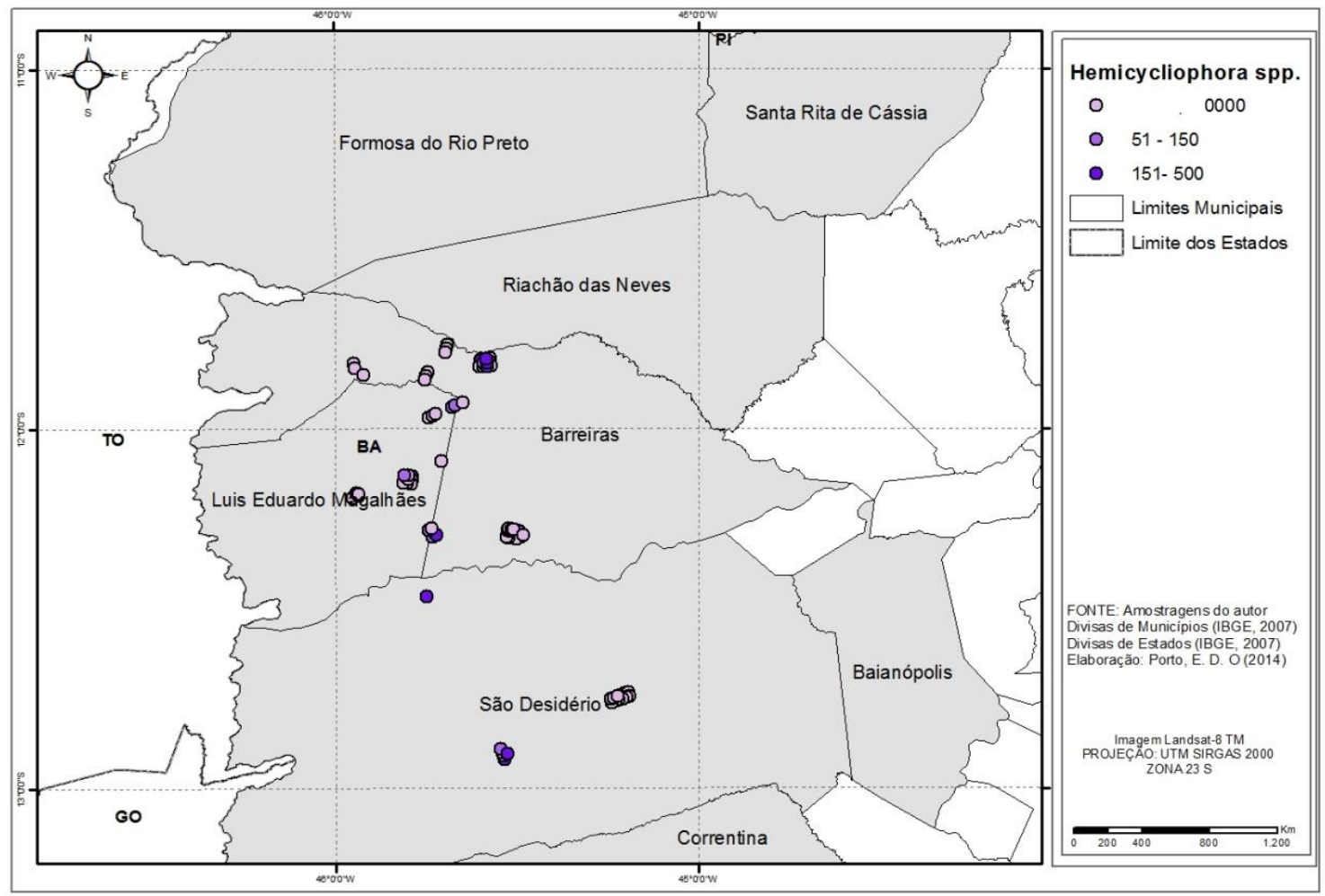

Figura 10: Mapa da distribuição de Hemicycliophora spp. na região oeste da Bahia e os intervalos das populações encontradas em $300 \mathrm{~cm}^{3}$ de solo.

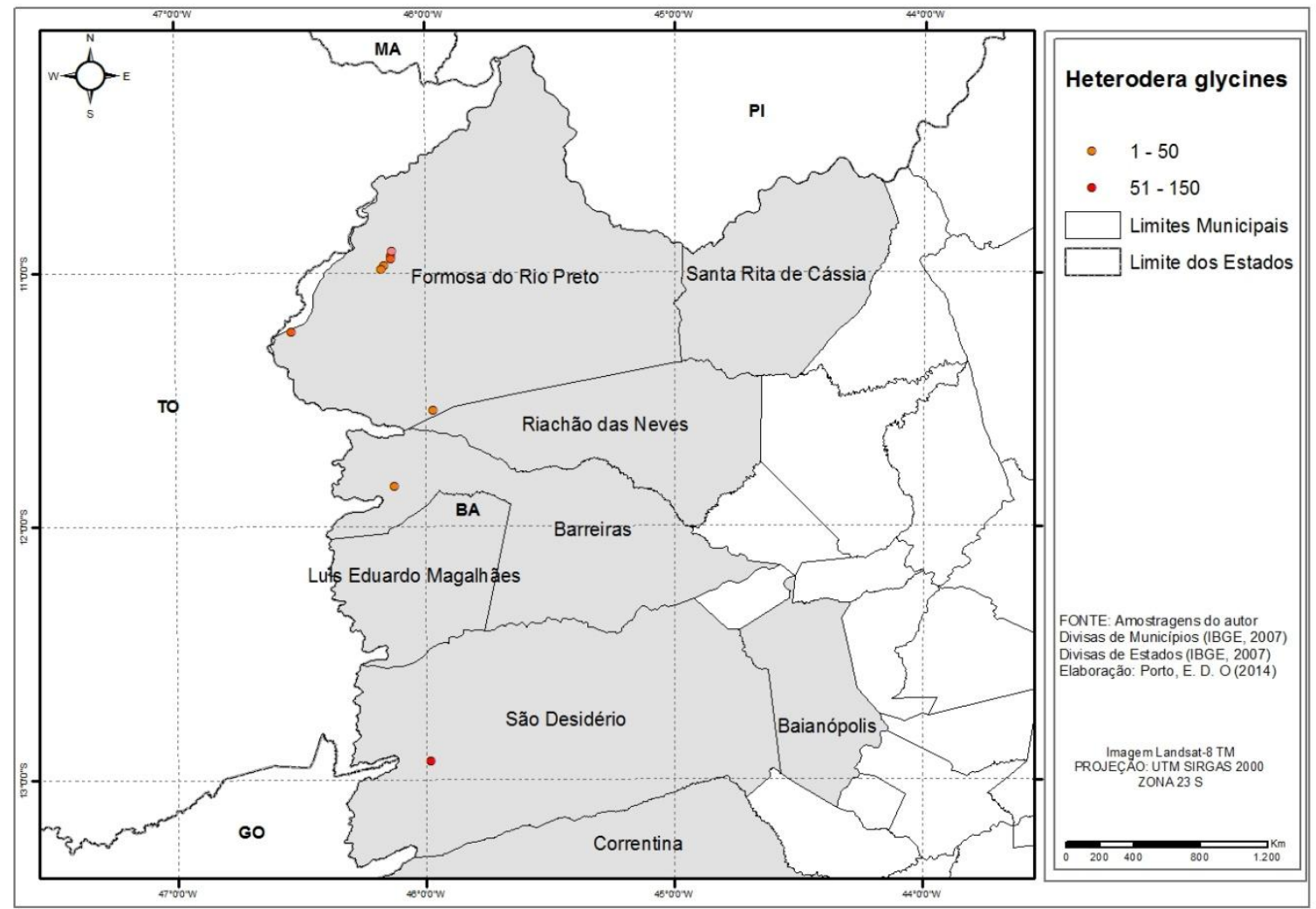

Figura 11: Mapa da distribuição de Heterodera glycines (J2) na região Oeste da Bahia e os intervalos das populações encontradas em $300 \mathrm{~cm}^{3}$ de solo. 


\section{DISCUSSÃO}

Os prejuízos causados por fitonematoides para a agricultura do Oeste da Bahia são sentidos pelos produtores, mas ainda são poucos os estudos que visam retratar a presença, distribuição e nível populacional desses organismos nas diferentes culturas da região. Baseado em estudos anteriores, sabe-se que $H$. glycines foi encontrado nos municípios de Formosa do Rio Preto e São Desidério (Dias et al. 2006), P. brachyurus, M. incognita e R. reniformis estavam presentes em cultivos de algodão nos municípios de Barreiras, Formosa do Rio Preto e Riachão das Neves (Matos et al., 2010), P. brachyurus, Helicotylenchus spp. e Hemicycliophora spp. em cafezais nos municípios de Barreiras, Luiz Eduardo Magalhães e São Desidério (Souza et al., 2003).

\subsection{DISTRIBUIÇÃO DOS NEMATOIDES FITOPARASITAS}

Os fitonematoides encontradas neste estudo: Pratylenchus spp., Meloidogyne spp., Helycolylenchus spp., Rotylenchulus reniformis, Heterodera glycines, Hemicycliophora spp., Scutellonema spp., Hoplolaimus spp., Criconemoides spp., Discocriconemella spp., e Paratrichodorus spp., são de ocorrência generalizada em solos do cerrado brasileiro, sendo sua presença e abundância variável de acordo com as diferentes cultivares plantadas (RODRIGUES, 2011; ARIEIRA, 2012). Enquanto, Gracilacus spp., Trichodorus spp. e Nothocriconemoides spp., embora já tenham sido relatados no cerrado, (HUANG \& RASKI, 1986; MATOS et al., 2008; RODRIGUES, 2011,) não são de ocorrência frequente.

Nas áreas de cerrado, foi encontrada a maior diversidade de nematoides fitoparasitas dentre os sistemas estudados, embora ocorrendo em baixos níveis populacionais, enquanto que nas áreas utilizadas para agricultura, observou-se alguns gêneros ocorrendo com frequências e populações muito elevadas. Em estudos anteriores já havia sido observada uma maior diversidade de espécies em áreas de vegetação nativa, assim como a ocorrência de fitoparasitas que se mostram mais abundantes em culturas do que no sistema nativo que lhes 
serviu de habitat original (HUANG E CARES, 1995; MATTOS, 1999; TOMAZINI et al., 2008).

De maneira geral, tem sido admitido que os cultivos anuais (particularmente as monoculturas) tendem a favorecer espécies de determinados gêneros de fitonematoides, que se tornam mais abundantes após a transformação de ecossistemas nativos em agroecossistemas (YEATES, 1999; GOULART et al., 2003).

\section{Helicotylenchus}

Espécimes do gênero Helicotylenchus esteviveram presentes em 58,3\% das amostras de solo, apresentando maior frequência nas áreas de algodão e de soja confirmando que é um nematoide que se adapta bem às condições dos cultivos anuais. Outros autores destacaram o gênero Helicotylenchus como o mais frequente em solos de cerrado com vegetação nativa, com culturas anuais ou culturas perenes, embora em cerrado estivesse presente com abundâncias inferiores às áreas cultivadas. (GOMES et al., 2003; CASTRO et al., 2008; MATTOS et al., 2008;). Helicotylenchus spp. geralmente não estão associados a danos expressivos nas culturas, embora ocorra com muita frequência no solo e geralmente em elevadas populações nos cultivos anuais (TOMAZINI et al., 2008).

\section{Pratylenchus}

Pratylenchus spp. foi o segundo grupo de nematoides que ocorreu com maior frequência nas amostras de solo (56\%), porém considerando as amostras de raízes, representantes desse gênero estiveram presentes em 67\%, já que este é um endoparasita obrigatório, portanto são encontrados em maior quantidade nas raízes das hospedeiras. Diversos autores apontam $P$. brachyurus como a espécie mais presente nas áreas cultivadas com culturas anuais especialmente soja (SHARMA et al., 2001; COMUNELLO E ASMUS, 2003; SILVA et al., 2003; SILVA, 2007). 
Dentre as culturas avaliadas, o algodão foi a que apresentou maior incidência de Pratylenchus (97,3 \% das amostras de raízes) e em seguida a soja (92\%). Embora para a cultura do algodão esse não seja um parasita causador de grandes prejuízos (MACHADO et al., 2006), o cultivo de algodão pode aumentar a população do nematoide que é capaz de causar danos para a soja, geralmente utilizada em rotação com o algodão no oeste da Bahia. A implicância econômica de P. brachyurus tem aumentado ao longo dos anos e Goulart (2008) relaciona a rotação ou sucessão com culturas que são boas hospedeiras do nematoide, tais como: a maioria dos genótipos de soja, feijão, algodão, milho, sorgo além de vários genótipos de milho e milheto, como uma das causas desse aumento.

Foi possível observar também que apesar da frequência ter sido maior em algodão as populações encontradas na soja foram mais altas, chegando a 2024 nematoides em $10 \mathrm{~g}$ de raizes. Machado e colaboradores (2006) demonstraram que P. brachyurus é pouco agressivo ao algodoeiro, em experimento em que somente populações superiores a 12.000 nematoides por planta causaram redução no crescimento das mesmas. No entanto na soja os danos são mais notáveis, segundo Goulart (2008) produtores no Brasil relatam perdas de produção em torno de 30 até $50 \%$ em áreas infestadas na região Centro-Oeste sob plantio direto.

Nas áreas de cultivo de café foram encontradas populações muito baixas do nematoide o que pode ser atribuído à baixa hospedabilidade do café a Pratylenchus brachyurus. De acordo com Oliveira et al. (1999) o cafeeiro demonstra intolerância e hipersensibilidade, não permitindo a reprodução do nematoide, porém sofre danos consideráveis, mesmo com populações baixas do parasita. Nessas áreas não foram encontradas espécies mais agressivas ao cafeeiro como P. coffeae, que foi encontrada causando severos danos a cafezais em Pernambuco (MOURA et al. 2002). Em levantamento de fitonematoides realizado no Planalto da Conquista e Chapada Diamantina na Bahia 15,9\% dos cafeeiros nos seis municípios 
amostrados estavam infestados com $P$. brachyurus em associação com $M$. incognita e $M$. exigua. (SOUZA et al. 2000).

Pratylenchus foi encontrado em cerrado com frequências (16\% das amostras de solo e $36 \%$ das amostras de raízes) e populações inferiores às encontradas nas culturas anuais e perene, nessas áreas o nível populacional de espécies mais adaptadas, tende a aumentar ao longo dos anos de cultivo. O gênero Pratylenchus congrega nematoides polífagos que podem parasitar um elevado número de espécies vegetais, porém existindo claras diferenças de preferências de hospedeiras entre as espécies (GOULART, 2008).

\section{Rotylenchulus reniformis}

Nas amostras coletadas em áreas de cerrado, foram identificados espécimes de $R$. reniformis em nove das quinze fazendas, e em $19 \%$ das amostras de solo de cultivos de algodão, apresentando grande variação populacional dentro de uma mesma área, chegando a 4106 indivíduos por $300 \mathrm{~cm}^{3}$ de solo. A variação populacional existente entre amostras coletadas em áreas de reboleiras e áreas fora das reboleiras é muito grande, de acordo com trabalho de Asmus e Isemberg (2003) que encontraram nas reboleiras populações que variaram de 4370 a 11360 nematoides $/ 200 \mathrm{~cm}^{3}$ de solo, enquanto fora das reboleiras, a população de $R$. reniformis foi de até 40 nematoides $/ 200 \mathrm{~cm}^{3}$ de solo. Além da variação das populações do nematoide em uma área, outros fatores contribuem para que a presença do $R$. reniformis seja muitas vezes subestimada nas amostragens de campo: Os sintomas provocados por $R$. Reniformis na parte aérea das plantas são muitas vezes confundidos com os causados por outros fatores como desordem nutricional ou compactação do solo (ASMUS E ISHIMI, 2009) e ainda, segundo Robinson et al. (2005) e Asmus e Ishimi (2009) as maiores populações de $R$. reniformis se encontram em profundidades superiores a $30 \mathrm{~cm}$ no solo, quando geralmente são coletadas amostras na camada de $0-20 \mathrm{~cm}$ de profundidade. Asmus e 
Isemberg (2003) relataram perdas em torno de $60,6 \%$ no rendimento de algodão em caroço nas áreas onde foram encontradas as maiores populações do nematoide (1000 nematoides/200 $\mathrm{cm}^{3}$ de solo) em relação a áreas que não exibiam sintomas de ataque do nematoide. Quanto ao limiar de danos para $R$. reniformis em algodão, Asmus (2004) considerou 300 juvenis $/ 100 \mathrm{~cm}^{3}$ de solo, valor que foi superado pelas densidades populacionais máximas encontradas no presente estudo (1368 indivíduos $/ 100 \mathrm{~cm}^{3}$ de solo). O potencial desse nematoide em causar danos aos plantios de algodão da região oeste da Bahia foi relatado por Matos et al., (2010) ao encontrarem níveis populacionais de até 1136 nematoides por $100 \mathrm{~cm}^{3}$ de solo.

\section{Heterodera glycines}

Foi detectada a presença de juvenis de $H$. glycines nos municípios de Formosa do Rio Preto, São Desidério e Barreiras, demonstrando tendência de disseminação progressiva deste nematoide na região. Desde o primeiro levantamento da distribuição de $H$. glycines no Brasil realizado por Mendes e Machado (1992) que identificaram essa espécie em municípios de Minas Gerais, Goiás, Mato Grosso e Mato Grosso do Sul, este nematoide vem sendo encontrado em diversos outras regiões produtores de soja. Em 2004 Dias et al. (2006) fizeram o primeiro relato oficial da presença de $H$. glycines nos municípios de Formosa do Rio Preto e São Desidério na Bahia dentre outros municípios de Tocantins, Mato Grosso e Paraná.

Embora as populações encontradas no presente estudo estivessem em níveis muito baixos, a simples presença do nematoide na região já é motivo de preocupação, pois o potencial de danos desse nematoide é muito elevado chegando a causar $90-100 \%$ de perdas na produção. Segundo Mendes e Machado, (1992) não existem níveis de infestação leves para H. glycines, pois qualquer número de cistos diferente de zero já representa um potencial de danos para a cultura.

\section{Hemicycliophora}


A ocorrência de espécimes de Hemicycliophora foi limitada às áreas de cultivo de café e nestas áreas o nível populacional encontrado indica uma adaptação desse nematoide ao cafeeiro ou a plantas invasoras da cultura. Alguns trabalhos associam Hemicycliophora spp. a cafeeiro e outras culturas perenes como goiaba e citros, hospedeiras conhecidas de $H$. catarinensis Manso, 1996 e H. arenaria Raski, 1958 respectivamente (TORRES et al., 2005). De acordo com Yeates (1991), a maioria os nematoides pertencentes à superfamilia Criconematoidea são mais sensíveis a distúrbios ambientais como arações, decorrentes de cultivos anuais, ocorrendo geralmente em altas populações em cultivos perenes como frutíferas, florestas e em matas nativas.

\subsection{POPULAÇÕES DE Meloidogyne spp.}

A maioria das populações de Meloidogyne spp. foi oriunda de áreas de cultivo de café, porém as raízes coletadas não apresentavam sintomas de galhas, os níveis populacionais em geral foram baixos e os proprietários das fazendas amostradas, não relataram prejuízos ocorridos devido à presença de nematoides, no entanto, em uma propriedade no município de São Desidério foi encontrada uma população máxima de 205 juvenis em $300 \mathrm{~cm}^{3}$ (68,3 J2/ $100 \mathrm{~cm}^{3}$ de solo), segundo Barbosa (2003), lavouras novas de café no Estado do Rio de Janeiro apresentaram perdas de produtividade de 30\%, e $45 \%$ nas lavouras velhas para níveis populacionais de 40 a $50 \mathrm{~J} 2 / 100 \mathrm{~cm}^{3}$ de solo. Souza et al. (2003) ao analisarem amostras de raízes de café de plantios no oeste da Bahia, não detectaram nenhuma forma do ciclo de vida de Meloidogyne spp. ou sintoma de galhas nas raízes. Todavia, na região cafeeira do Planalto da Conquista e Chapada Diamantina, 57,3\% dos cafeeiros se encontraram infectados com $M$. exigua e $18,1 \%$ com $M$. incognita e ainda $15,9 \%$ estavam infestados com nematoides das lesões, Pratylenchus sp., associados a M. exigua e/ou M. incognita (Souza et al., 2000).

O estudo dos perfis de esterase revelou que as populações encontradas pertenciam em sua maioria à espécie $M$. javanica. O cafeeiro apresenta baixa hospedabilidade para esta 
espécie (CARNEIRO, 2005), diferentemente das espécies $M$. paranaensis, M. exigua e $M$. incognita estando esta última, presente em $24 \%$ das populações neste estudo. Sugere-se a possibilidade de que muitas das populações de Meloidogyne encontradas, estarem sobrevivendo associadas ao sistema radicular de algumas plantas invasoras. Antonio e Lehman (1978) identificaram $M$. incognita, M. javanica, M. arenaria e Meloidogyne spp. formando galhas em 18 espécies de ervas daninhas, no Paraná e Rio Grande do Sul, Zem e Lordello (1976), encontraram dezoito espécies de fitonematoides dentre estas: Meloidogyne incognita e $M$. javanica ao analizar raízes de 78 espécies de plantas daninhas, dentre elas a Maria-pretinha Solanum americanum Mill., solanácea muito comumente encontrada nos cafezais do oeste da Bahia.

No algodão prevaleceu a espécie $M$. incognita. Nessas áreas foi possível observar reboleiras de plantas com o sintoma de folhas carijó e formação de galhas no sistema radicular principalmente nas raízes periféricas, embora a frequência desse nematoide nos cultivos de algodão tenha sido baixa (18,7\% das amostras de solo) os níveis populacionais foram muito elevados, chegando a $4366 \mathrm{~J} 2 \mathrm{em} 300 \mathrm{~cm}^{3}$ de solo, o que indica que a espécie se encontra bem adaptada à cultura e causando perdas, considerando o nível de danos proposto por Asmus, (2004) de $50 \mathrm{~J} 2 / 100 \mathrm{~cm}^{3}$ de solo. No Brasil, M. incognita tem ocorrência generalizada, estando distribuída praticamente por todas regiões produtoras de algodão do país. (SILVA et al., 2004). Page e Bridge (1976) relataram a espécie M. acronea causando galhas em algodão no sul do continente africano, porém no Brasil não foram encontrados relatos de outras espécies de Meloidogyne parasitando essa cultura, e das quatro raças fisiológicas de $M$. incognita descritas na literatura, apenas as raças 3 e 4 são parasitas do algodoeiro (SUASSUNA et al., 2006).

Das populações obtidas de cultivos de soja, $77 \%$ pertenciam à espécie $M$. javanica, e 30,7\% a M. incognita. Franzener et al. (2005) também identificaram M. javanica e $M$. 
incognita em cultivos de soja do oeste do Paraná sendo M. javanica a espécie mais frequente. Em levantamento de espécies do gênero Meloidogyne realizado nas principais regiões produtoras de soja no Brasil, Castro et al. (2003) encontraram M. javanica na maioria $(64,1 \%)$ das populações. Segundo Dias et al. (2010) no Brasil $M$. javanica tem ocorrência generalizada, enquanto $M$. incognita predomina em áreas cultivadas anteriormente com café ou algodão.

Espécimes de Meloidogyne ocorreram em oito das quinze fazendas em áreas de cultivo de soja, com populações baixas (até $5 \mathrm{~J} 2 / 300 \mathrm{~cm}^{3}$ de solo) e muito elevadas (até 1404 $\mathrm{J} 2 / 300 \mathrm{~cm}^{3}$ de solo), e destas, somente em três propriedades os níveis de danos não foram alcançados: $50 \mathrm{~J} 2 / 100 \mathrm{~cm}^{3}$ de solo, para $M$. javanica e $250 \mathrm{~J} 2 / 100 \mathrm{~cm}^{3}$ de solo para $M$. incognita (ASMUS, 2001), considerando que a maioria das populações encontradas pertenciam à espécie $M$. javanica .

Ambas as espécies $M$. incognita e $M$. javanica foram encontradas nas áreas de cerrado próximo às áreas cultivadas indicando a presença natural de espécies de Meloidogyne neste bioma, estudos anteriores apontaram $M$. javanica como a espécie mais presente nas diferentes fitofisionomias do cerrado (SILVA, 2012; SOUZA et al., 1994). Ao longo do tempo, os cultivos sucessivos vão selecionando as espécies mais adaptadas a cada cultura (GOULART, 2008).

As maiores populações de Meloidogyne foram encontradas nos municípios de barreiras, Luiz Eduardo Magalhães e Formosa do Rio Preto nas culturas de soja e algodão. Espécimes dos gêneros Meloidogyne e Pratylenchus foram encontrados nas áreas de cerrado em todas as fazendas nas amostras de solo ou nas de raízes, isso demonstra a presença natural de espécies desses gêneros que inicialmente encontram-se em baixos níveis populacionais, 
mas que ao longo do tempo tem sua população aumentada devido ao cultivo continuo de plantas hospedeiras nessas áreas. 


\section{CONCLUSÕES}

Nas áreas de vegetação nativa de cerrado foi encontrada a maior diversidade de nematoides fitoparasitas em relação às áreas cultivadas com soja, algodão e café.

Os nematoides mais frequentemente encontrados associados às culturas da soja, algodão e café foram Pratylenchus, Meloidogyne e Rotylenchulus, que ocorreram em altos níveis populacionais, representando elevado potencial de danos às culturas.

Espécimes de Hemicycliophora só ocorreram em associação com cafeeiros.

A principal espécie de Meloidogyne encontrada foi $M$. javanica, embora M. incognita também tenha ocorrido com frequência.

A espécie Pratylenchus brachyurus foi a encontrada com maior frequencia nesse estudo.

O nematoide de cisto da soja, Heterodera glycines embora esteja presente na região, não se encontra muito disseminado, portanto sugere-se adoção de medidas que visem evitar a entrada deste fitonematoide nas áreas ainda não afetadas. 


\section{REFERÊNCIAS BIBLIOGRÁFICAS}

ABRAPA - Associação Brasileira dos Produtores de Algodão. 2015. Disponível em:

<http://abrapa.com.br/>. Acessado em: 22 jan. 2015.

AGRIOS, G. N. 2005. Plant diseases caused by nematodes. In: AGRIOS, G. N. (Ed.). Plant Pathology. 5th ed. San Diego: Elsevier Academic Press 826-865

AIBA - Associação de Agricultores e Irrigantes da Bahia. 2014. Anuário da Região Oeste da Bahia 107.

ALONSO, S.K. de \& ALFENAS A.C. 1998. Isoenzimas na taxonomia e na genética de fitonematoides. In: A.C. Alfenas (Ed.). Eletroforese de isoenzimas e proteínas afins, fundamentos e aplicações em plantas e microrganismos. Viçosa Editora: UFV 574.

ANTONIO, H. \& LEHMAN, P. S. 1978. Nota sobre a ocorrência de nematoides do gênero Meloidogyne em algumas ervas daninhas nos estados do Paraná e do Rio Grande do Sul. Sociedade Brasileira de Nematologia. Londrina.

ARIEIRA, G. O. 2012. Diversidade de nematoides em sistemas de culturas e manejo do solo. (Dissertação) Mestrado em agronomia, Universidade Estadual de Londrina, Londrina 96.

ASMUS, G. L. \& ISENBERG, K. 2003. Danos em algodoeiro associados ao nematoide reniforme (Rotylenchulus reniformis) em Mato Grasso do Sul. In: CONGRESSO BRASILEIRO DE ALGODÃO, Goiânia. Campina Grande: Embrapa Algodão.

ASMUS, G.L. 2001. Danos causados à cultura da soja por nematoides do gênero Meloidogyne. In: FERRAZ, L. C. C. B.; ASMUS, G. L.; CARNEIRO, R. G.; MAZAFFERA, 
P. \& SILVA, J. F. V. Relações parasito-hospedeiro nas meloidoginoses da soja. Londrina. Embrapa Soja 39-62.

ASMUS, G.L. 2004. Ocorrência de nematóides fitoparasitos em algodoeiro no Estado de Mato Grosso do Sul. Nematologia Brasileira 28: 77-86.

ASMUS, L. G. \& ISHIMI, C. M. 2009. Flutuação populacional de Rotylenchulus reniformis em solo cultivado com algodoeiro. Pesquisa Agropecuária Brasileira, Brasília 44(1): 51-57.

BARBOSA, D. H. S. G. 2003. Levantamento dos nematóides de galha (Meloidogyne spp.) em áreas cafeeiras fluminenses e estimativas dos seus danos à produtividade regional. Dissertação (Mestrado em Produção Vegetal) Universidade Estadual do Norte Fluminense - Campos dos Goytacazes 89.

BRANDÃO, G. 2011. História da produção de café no Brasil. Disponível em: <http://www.administradores.com.br/artigos $>$. Acessado em 25 jan. 2015.

BRIDGE J. 1992. Nematodes. In: HILLOCKS, R. J. (Ed). Cotton diseases. Eerley Gate: univesity of Reading, CAB International 331-354.

CAMPOS, V. P. 1997.Controle de doenças: Doenças causadas por nematoides. In: VALE, F. X. R. \& ZAMBOLIM, L. (Ed.). Controle de doenças de plantas: grandes culturas. Viçosa: Editora UFV 141-180.

CARES, J. E. \& HUANG, S. P. 2008. Comunidades de nematoides de solo sob diferentes sistemas na Amazônia e cerrados brasileiros. In: MOREIRA, F. M. S.; SIQUEIRA, J. O. \& BRUSSAARD, L. (Eds.). Biodiversidade do solo em ecossistemas brasileiros. Lavras: Editora UFLA 409-444. 
CARES, J. H. \& HUANG, S. P. 1991. Nematode fauna in natural and cultivated cerrados of Central Brazil. Fitopatologia Brasileira, Brasília 16 (3): 199-209.

CARNEIRO, R. M. D. G. \& ALMEIDA, M. R. A. 2000. Caracterização isoenzimática e variabilidade intraespecífica dos nematoides de galhas do cafeeiro no Brasil. In: SIMPÓSIO DE PESQUISA DOS CAFÉS DO BRASIL, Poços de Calda. Brasília: Embrapa Café 280282.

CARNEIRO, R. M. D. G. \& ALMEIDA, M. R. A. 2001. Técnica de eletroforese usada no estudo de enzimas dos nematoides de galhas para identificação de espécies. Nematologia Brasileira, Piracicaba 25(1)35-44.

CARNEIRO, R. M. D. G.; RANDING, O.; ALMEIDA, M. R. A. \& GONÇALVES,W. 2005. Identificação e caracterização de espécies de Meloidogyne em cafeeiros nos estados de São Paulo e Minas Gerais através dos fenótipos de esterase e SCAR-Multiplex-PCR. Nematologia Brasileira, Piracicaba 29(2): 233-241.

CARNEIRO, R. M. D. G \& COFCEWICZ, E.T. 2008. Taxonomy of coffee-parasitic rootknot nematodes, Meloidogyne spp. In: SOUZA, R. M. Plant parasitic nematodes of coffee. Springer, Holand, 87-122.

CARVALHO, L.V.; ALMEIDA, E. J.; LEÃO, E. F.; SANTOS, L. L. \& ARAÚJO, M. S. 2010. Estudo da Nematofauna de Áreas Preservadas e Cultivadas de Cerrado em Ipameri-GO. In: Anais V Jornada de Pesquisa e Pós-Graduação.

CASTRO, J. M. C.; CAMPOS, V. P.; POZZA, E. A.; NAVES, R. L.; JUNIOR, W. C. A.; DUTRA, M. R.; COIMBRA, J. L.; MAXIMINIANO, C. \& SILVA, J. R. C. 2008. 
Levantamento de fitonematoides em cafezais do Sul de Minas Gerais. Nematologia Brasileira, Piracicaba 32(1): 56-64.

CASTRO, J. M. C.; NAVES, R. L. \& CAMPOS, V. P. 2003. Ocorrência de Meloidogyne paranaensis em cafeeiro na região do Alto Paranaíba em Minas Gerais. Fitopatologia Brasileira 28(5): 565.

CISOJA - Centro de Inteligência da Soja. 2009. Disponível em: 〈http://www.cisoja.com.br/>. Acessado em: 25 jan 2015.

COMUNELLO, E. \& ASMUS, G. L. 2003. Ocorrência de nematoides fitoparasitos em lavouras de algodão no Estado de Mato Grosso do Sul, ano agrícola de 2001/2002. Embrapa.

CONAB - Companhia Nacional de Abastecimento. 2014. Disponível em: <http://www.conab.gov.br/>. Acessado em: 20 jan 2015.

COSTA, D. H. \& MONDARDO, M. L. 2013. A modernização da agricultura no oeste baiano: migração sulista e novas territorialidades. Revista Geonorte 7(1): 1371-1385.

CUNHA, R.P.; MAIA, G.L.; RODACKI, M.E.P.; SILVA, G.S. \& MEYER, M.C. 2008. Ciclo de vida de Heterodera glycines raça 9 em soja no Maranhão. Summa Phytopathologica 34(3): 262-264.

DIAS, W. P.; GARCIA, A.; SILVA, J. F. V. \& CARNEIRO, G. E. S. 2010. Nematoides em soja: Identificação e controle. Londrina: Embrapa Soja. Circular Técnica 76.

DIAS, W. P.; SILVA, J. F. V.; GARCIA, A. \& CARNEIRO, G. E. de S. 2004 Biologia e controle de nematoide de cisto da soja (Heterodera glycines Ichinohe). In: SARAIVA, O. F.; 
LEITE, R. M. V. B. de C. 2006. Resultados de pesquisa da Embrapa Soja Londrina. Embrapa Soja 10-13.

EMBRAPA - Empresa Brasileira de Pesquisa Agropecuária. 2000. A cultura da soja no Brasil. Londrina: Embrapa Soja 179.

EMBRAPA - Empresa Brasileira de Pesquisa Agropecuária. 2004. Tecnologias de produção de soja - região central do Brasil. Londrina: Embrapa Soja, 2004. Disponível em:< http://www.cnpso.embrapa.br/> Acesso em: 25 jan. 2015.

EMBRAPA - Empresa Brasileira de Pesquisa Agropecuária. 2011. Tecnologias de Produção de Soja - Região Central do Brasil 2012 e 2013. Embrapa Soja. Sistemas de Produção 15.

EMBRAPA - Empresa Brasileira de Pesquisa Agropecuária. 2014. Novas cultivares de soja de elevada produtividade são lançadas na Bahia - Produção Vegetal Embrapa Soja, Disponível em:< https://www.embrapa.br/busca-de-noticias/> Acesso em: 02 fev. 2015.

ESBENSHADE, P. R. \& TRIANTAPHYLLOU, A. C. 1990. Isozyme phenotypes for the identification of Meloidogyne species. Journal of Nematology 22: 10-5.

FERRAZ, L. C. C. B. 1995. Interações entre de Pratylenchus brachyurus e Meloidogyne javanica em soja. Scientia Agricola, Piracicaba 52(2): 305-309.

FRANZENER, G.; UNFRIED, J. R.; STANGARLIN, J. R. \& FURLANETTO, C. 2005. Nematoides formadores de galhas e cisto patogênicos à cultura da soja em municípios do oeste do Paraná. Nematologia Brasileira 29(2): 261-265. 
GIELFI, F.S.; SANTOS, J. M. \& ATHAYDE, M .L. F. 2003. Reconhecimento das espécies de fitonematóides associadas ao algodoeiro (Gossypium hirsutum L.) no estado de Goiás. In: CONGRESSO BRASILEIRO DO ALGODÃO, Goiânia. Campina Grande: Embrapa Algodão.

GOMES, G. S.; HUANG, S. P. \& CARES, J. E. 2003. Nematode community, trophic structure and population fluctuation in soybean fields. Fitopatologia Brasileira 28: 258-266.

GONÇALVES, W. 2000. Manejo de fitonematoides em cafeeiro no Estado de São Paulo. In: Anais do Congresso Brasileiro de Nematologia, 22, Uberlândia 42-43.

GONÇALVES, W. \& SILVAROLLA, M. B. 2001. Nematoides parasitos do cafeeiro. In: ZAMBOLIM, L. Tecnologias de produção de café com qualidade. Viçosa: UFV 199-267.

GOULART, A. M. C. 2008. Aspectos gerais sobre nematoides das lesões radiculares (Gênero Pratylenchus). Planaltina: Embrapa Cerrados. Documentos 219.

GOULART, A. M. C.; MARCHÃO, R. L.; VILELA, L.; JUNIOR, J. D. G. dos S. \& SÁ; M. C. 2008. Diversidade de nematoides em um latossolo vermelho sob sistemas de integração lavoura-pecuária no cerrado. In: IX Sinpósio Nacional do Cerrado. Brasilia.

GOUlART, A. M. C; MONTEIRO, A. R. \& FERRAZ, L. C. C. B. 2003. Comunidades de nematoides em cerrado com vegetação original preservada ou substituída por culturas. Nematologia Brasileira 27(2): 129-137.

HENNING, A. A.; ALMEIDA, A. M. R.; GODOY, C. V.; SEIXAS, C. D. S.; YORINORI, J. T.; COSTAMILAN, L. M.; FERREIRA, L. P.; MEYER, M. C.; SOARES, R. M. \& DIAS, W. 
P. 2014. Manual de identificação de doenças de soja. Embrapa Soja, Documentos 256 Londrina 76.

HUANG, C. S. \& CUPERTINO, F. P. 1976. Nematoides parasitas de plantas em áreas cultivadas do Distrito Federal e Goiás. Revista da Sociedade Brasileira de Fitopatologia 9: 29.

HUANG, S.P. \& CARES, J. H. 1995. Community composition of plant-parasitic nematodes in native and cultivated cerrados of Central Brazil. Journal of Nematology 27: 237-243.

IAC - Instituto Agronómico. 2015. Disponível em:

<http://www.iac.sp.gov.br/areasdepesquisa/cafe/>. Acessado em: 04 mar 2015

IBGE - Instituto Brasileiro de Geografia e Estatística. 2014. Disponível em:

<http://www.ibge.gov.br/>. Acessado em: 25 jan 2015.

ILARIO, C. G. 2013. A região agrícola competitiva do Oeste Baiano. Boletim Campineiro de Geografia 3:(1).

INOMOTO, M. M.; ASMUS, G. L.; SILVA, R. A. da. \& MACHADO, A. C. Z. 2007a.

Nematoides: uma ameaça à cotonicultura brasileira. Syngenta Proteção de Cultivos Ltda 14.

INOMOTO, M. M.; GOULART, A. M. C.; MACHADO, A. C. Z. \& MONTEIRO A. R. 2001. Effect of population densities of Pratylenchus brachyurus on growth of cotton plants. Fitopatologia Brasileira 26(2): 192-196.

INOMOTO, M. M.; KUBO, R.K.; SILVA, R.A.; OLIVEIRA, C.M.G.; TOMAZINI, M.D. \& MAZZAFERA, P. 2007b. Pathogenicity of two Pratylenchus coffeae populations from Brazil on coffee plants. Nematolog, 9(6): 853-858. 
INOMOTO, M. M.; OLIVEIRA, C.M.G.; MAZZAFERA, P. \& GONÇALVES, W.

1998. Effects of Pratylenchus brachyurus and P. coffeae on seedlings of Coffea arabica. Journal of Nematology 30: 362-367.

JENKINS, W. R. 1964. A rapid centrifugal-flotation technique for separating nematodes from soil. Plant Desease Reporter 48(9): 692.

LORDELLO, L. G. E. 1984. Nematoides das plantas cultivadas. $8^{a}$ ed. São Paulo, Ed. Livraria Nobel 314.

LUNARDON, M. T. Análise da conjuntura agropecuária safra 2007/08 algodão. 2007. Secretaria da Agricultura e do Abastecimento. Disponível em: 〈http//www.seab.pr.gov.br〉. Acesso em: 25 jan. 2015.

MACHADO, A. C. Z.; BELUTI, D. B.; SILVA, R. A.; SERRANO, M. A. S. \& INOMOTO, M. M. 2006. Avaliação de danos causados por Pratylenchus brachyurus em algodoeiro. Fitopatologia Brasileira 31: 11-16,

MAPA - Ministério da Agricultura Pecuária e Abastecimento. 2015. Disponível em: <http://www.agricultura.gov.br/>. Acesso em: 22 jan. 2015.

MATTOS, J. K. A. 1999. Caracterização das comunidades de nematoides em oito sistemas de uso da terra nos cerrados do Brasil Central. Tese (Doutorado em Fitopatologia) Universidade de Brasília, Brasília 113.

MATTOS, J. K. A.; ANDRADE, E. P.; TEIXEIRA, M. A.; CASTRO, A. P. G. \& HUANG, S. P. 2008. Gêneros-chaves de onze diferentes comunidades de nematoides do solo na região dos cerrados do Brasil central. Nematologia Brasileira 32(2): 142-149. 
MATOS, P. S.; COIMBRA, J. L.; SANTOS, F. da S. \& SANTOS, J. B. 2010. Ocorrência de fitonematoides em plantios de algodão no oeste da Bahia. Revista de Biologia e Ciências da Terra 10(2): 29-38.

MATTOS, J. K. A.; HUANG, S. P. \& PIMENTEL, C. M. M. 2006. Grupos tróficos da comunidade de nematoides do solo em oito sistemas de uso da terra nos cerrados do Brasil central. Nematologia Brasileira, Brasília 30:(3)267-273.

MENDES, M. L. \& DICKISON, D. W. 1993.Detection of Heterodera glycines on soybean in Brasil. Plant Disease 77: 499-500.

MENDES, M.L. \& MACHADO, C.C. 1992. Levantamento preliminar da ocorrência do nematoide de cisto da soja (Heterodera glycines Ichinohe), no Brasil. Embrapa CNSPo. Comunicado Técnico 53.

MENDONÇA, J. O. 2006. O potencial de crescimento da produção de grãos no oeste da Bahia. Bahia Agrícola 7(2):38-46.

MOREIRA, J. U. V. \& PIPOLO, A. E. 2011. Cultivares de soja Bahia safra 2011/12 Embrapa Soja. Londrina-PR 21.

MOURA, R. M.; PEDROSA, E. M. \& PRADO, M. D. C. 2002. Incidência de Pratylenchus Coffeae causando severa nematose em cafeeiros no Nordeste. Fitopatologia Brasileira 27(6): 649.

MOURA, R. M. 1997. O gênero Meloidogyne e a meloidoginose. In: Luz, W. C. (Ed). Revisão Anual de Patologia de Plantas. Passo Fundo: Pe. Berthier 281-315. 
MOURA, R. M. de \& MARANHÃO, S. R. V. L. 2004. Dados históricos e projeções futuras sobre a Fitonematologia. In: Anais da Academia Pernambucana de Ciência Agronômica, Recife 1: 47-68.

NEHER, D. 2001. A. Role of nematodes in soil health and their use as indicators. Journal of Nematology 33(4): 161-168.

OLIVEIRA, C. M. G; INOMOTO, M. M.; VIEIRA, A. M. C. \& MONTEIRO, A. R. 1999. Efeito de densidades populacionais de Pratylenchus brachyurus no crescimento de plântulas de Coffea arabica cv. Mundo Novo e C. canephora cv. Apoatã. Nematropica 29: 215-221.

PAGE, S. L. J. \& BRIDGE, J. J. E. 1976. Meloidogyne acronea associated with reduced growth of cotton in Malawi. Plant Disease Report 60: 5-7.

RIBEIRO, N. R. 2009. Avaliação de espécies vegetais e cultivares de soja para a composição de esquemas de rotação ou sucessão de culturas para o manejo de Pratylenchus brachyurus. Tese (Doutorado em Agronomia). Universidade Estadual de Londrina, Londrina 56.

ROBINSON, A. F.; AKRIDGE, R.; BRADFORD, J. M.; COOK, C. G.; GAZAWAY, W. S.; KIRKPATRICK, T. L.; LAWRENCE, G. W.; LEE, G.; McGAWLEY, E. C.;

OVERSTREET, C.; PADGETT, B.; RODRÍGUEZ-KÁBANA, R.; WESTPHAL, A. \& YOUNG, L. D. 2005. Vertical distribution of Rotylenchulus reniformis in cotton fields. Journal of Nematology 37: 265-271.

RODRIGUES, C. S. \& BUENO, M. G. 2004. A saga do algodão: das primeiras safras a ação na OMC. Rio de Janeiro: Insight Engenharia 144. 
RODRIGUES, C da S. 2011. Comunidades de nematoides associadas às principais fitofisionomias do cerrado do parque nacional de Brasília. Dissertação (Mestrado em Fitopatologia) Universidade de Brasilia, Brasília 53.

SAES, M. S. M. \& NAKAZONE, D. 2004. O agronegócio café do Brasil no mercado internacional. Fae Business, 9 . Disponível em: 〈http://www.unifae.br/publicacoes/〉. Acesso em: 22 jan. 2015.

SANTOS, G. R. dos. 2005. Sistemas de manejo para o controle de Meloidogyne incognita em algodoeiro irrigado no oeste da Bahia. Dissertação (Mestrado em Fitopatologia). Universidade de Brasilia, Brasília 79.

SANTOS, J. M. 1997. Taxonomia de espécies de Meloidogyne Goeldi, 1889 que infectam o cafeeiro (Coffea spp.) no Brasil. Fitopatologia Brasileira 22: 229-230.

SHARMA, R. D.; CAVALCANTE, M. J. B.; MOURA, G. M. \& VALENTIM, J. F. 2001. Fitonematoides associados às cultivares de soja no estado do Acre. Planaltina: Embrapa Cerrados. Circular Técnica 56: 1-4.

SILVA, F. C. 2007. Levantamento de fitonematoides presentes no município de Jataí-GO. Dissertação (Mestrado em Agronomia) - Universidade Federal de Uberlândia, Uberlândia 47.

SILVA, J. G. P. 2012. Ocorrência de Meloidogyne spp. em diferentes fitofisionomias do cerrado e hospedabilidade de plantas nativas a Meloidogyne javanica. Dissertação (Mestrado em Fitopatologia) - Universidade de Brasilia, Brasília 63.

SILVA, R. A. da; SERRANO, M. A. S.; INOMOTO, M. M. \& ASMUS, G. L. 2004. Distribuição, dinâmica populacional e danos provocados por Meloidogyne incognita, 
Rotylenchulus reniformis e Pratylenchus brachyurus na cultura do algodoeiro no estado do Mato Grosso. Grupo de Produção Acadêmica de Ciências Agrárias e Biológicas. UIVAG, Várzea Grande 36.

SILVA, J.F.V.; GARCIA, A.; DIAS, W.P.; ASMUS, G.L. \& CARNEIRO, G.E.S. 2003. Manejo integrado de nematoides na cultura da soja. Fitopatologia Brasileira, BrasiliaDF 28: $30-34$.

SILVA, R. A.; SERRANO, M. A. S.; GOMES, A. S.; BORGES D. C.; SOUZA, A. A.; ASMUS, G. L. \& INOMOTO, M. M. 2003. Nematoides associados ao algodoeiro no estado do Mato Grosso. In: Congresso Brasileiro de Nematologia, XXIV. Petrolina, PE, Brasília: Sociedade Brasileira de Nematologia 24: 150.

SILVA, R.V.; OLIVEIRA, R. D. L.; PEREIRA, A. A. \& SÊNI, D. J. 2006. Otimização da produção de inóculo de Meloidogyne exigua em mudas de cafeeiro. Nematologia Brasileira, Piracicaba 30(3):229-238.

SOUZA, S. E.; AMARAL, R. N. S.; SANTOS, J. F.; OLIVEIRA, A. A. S.; OLIVEIRA, J. S.; ROCHA, A. S.; BRITO, Z. A. \& SILVA, E. B. 2003. Levantamento do nematóide das galhas Meloidogyne sp. em cafeeiros irrigados no oeste da Bahia. In: III Simpósio de Pesquisa dos Cafés do Brasil.

SOUZA, E. C. S.; SANTOS, O. A.; ARAÚJO, A. O. \& ARAÚJO, W. K. O. 2010. Oeste da Bahia: Novos Arranjos Espaciais. In: Anais XVI Encontro Nacional dos Geógrafos. Porto alegre 1-12.

SOUZA, R. M.; DOLINSKI, C. M. \& HUANG, S. P. 1994. Survey of Meloidogyne spp. in native cerrado of Distrito Federal, Brazil. Fitopatologia Brasileira 19: 463-465. 
SOUZA, S. E.; SANTOS, J. M.; MATOS, R. V.; RAMOS, J. A.; SANTOS, F. S.; FERRAZ, R. C. N.; CARVALHO, G. S. \& OLIVEIRA, C. A. 2000. Levantamento preliminar de Meloidogyne em cafeeiros no Estado da Bahia - planalto de Vitória da Conquista e Chapada Diamantina. In: Simpósio de Pesquisa dos Cafés do Brasil 167-170. Disponível em:< http://www.sapc.embrapa.br/arquivos/consorcio/spcb_anais/simposio1/Doencas1.pdf $>$. Acessado em: 20 jan. 2015.

SUASSUNA, N. D.; CHITARRA, L .G; ASMUS, G. L. \& INOMOTO, M. M. 2006. Manejo de Doenças do Algodoeiro. Campina Grande: EMBRAPA. Circular Técnica 97: 1-24.

TIHOHOD, D. 1993. Nematologia agrícola aplicada. Jaboticabal: FUNEP 372.

TOMAZINI, M. D.; FERRAZ, L. C. C. B. \& MONTEIRO, A. R. 2008. Abundância e diversidade de nematoides em áreas contíguas de vegetação natural e submetidas a diferentes tipos de uso agrícola. Nematologia Brasileira 32(3): 185-193.

TORRES, G. R. C.; PEDROSA, R. M. \& SALES JUNIOR, R. 2005. Hemicycliophora catarinensis associada à rizosfera de mudas de goiabeira no Nordeste. Nematologia Brasileira, Brasília 29(2): 303-305.

VIGLIERCHIO, D. R. 1991. The World of Nematodes: a fascinating component of the animal kingdom. Davis: University of California 266.

YEATES, G. W; BONGERS, T.; GOEDE, R. G. M.; FRECKAMN, D. W. \& GEORGIVA, S. S. 1993. Feeding habits in soil nematode families and genera - an outline for soil ecologists. Journal of Nematology 25: 315-331. 
YEATES, G.W. 1991. Ecological society impact of historical changes in land use on the soil fauna. New Zealand Journal of Ecology 15: 99-106.

YEATES, G.W. 1999. Effects of plants on nematode community structure. Annual Review of Phytopathology 37: 127-149.

ZEM, A. C. \& LORDELLO, L. G. 1976.Nematoides associados a plantas invasoras. Anais da Escola Superior de Agricultura Luiz de Queiroz 33: 597-615. 